Review

\title{
Ambient Air Quality in the Czech Republic: Past and Present
}

\author{
Iva Hůnová $\mathbb{D}$
}

Ambient Air Quality Department, Czech Hydrometeorological Institute, Na Šabatce 17, 14306 Praha 4, Czech Republic; iva.hunova@chmi.cz

Received: 7 January 2020; Accepted: 14 February 2020; Published: 20 February 2020

check for updates

\begin{abstract}
Based on an analysis of related core papers and reports, this review presents a historical perspective on ambient air pollution and ambient air quality development in the modern-day Czech Republic (CR) over the past seven decades, i.e., from the 1950s to the present. It offers insights into major air pollution problems, reveals the main hot spots and problematic regions and indicates the principal air pollutants in the CR. Air pollution is not presented as a stand-alone problem, but in the wider context of air pollution impacts both on human health and the environment in the CR. The review is arranged into three main parts: (1) the time period until the Velvet Revolution of 1989, (2) the transition period of the 1990s and (3) the modern period after 2000. Obviously, a major improvement in ambient air quality has been achieved since the 1970s and 1980s, when air pollution in the former Czechoslovakia culminated. Nevertheless, new challenges including fine aerosol, benzo[a]pyrene and ground-level ozone, of which the limit values are still vastly exceeded, have emerged. Furthermore, in spite of a significant reduction in overall emissions, the atmospheric deposition of nitrogen, in particular, remains high in some regions.
\end{abstract}

Keywords: air pollution; air quality; 1950-2018; Czechoslovakia; emissions; aerosol; ground-level ozone; atmospheric deposition; health outcomes; environmental issues

\section{Introduction}

The modern-day Czech Republic (CR), one of the two succession countries of the former Czechoslovakia post 1993, is a Central European country with an infamous environmental pollution history, including heavy air pollution with serious impacts in the past. These were mostly due to emissions from burning poor-quality lignite of local provenience with very high contents of sulphur used both for coal-powered thermal power plants and local, domestic heating systems. Extremely high $\mathrm{SO}_{2}$ emissions affected the health of the inhabitants adversely and resulted in serious environmental damage, including the decline of spruce forests. Furthermore, emissions from high stacks of large power plants added substantially, due to long-range transport, to acid rain and the acidification of ecosystems in other European regions, such as Scandinavia. The infamous 'Black Triangle', a border region situated between the former Czechoslovakia, East Germany and Poland, belonged to the most polluted areas of Europe at that time.

As a consequence of fundamental socioeconomic changes triggered by the Velvet Revolution of 1989, the introduction of new legislation, application of effective countermeasures in emission reduction and modernisation of energy production and industry, alongside extensive gasification of local heating systems, the overall situation in ambient air quality has improved substantially. An unprecedented reduction in $\mathrm{SO}_{2}$ emissions of some $90 \%$ has been recorded, accompanied by reductions in TSP (total suspended particles) and $\mathrm{NO}_{\mathrm{x}}$ (nitrogen oxides). Nevertheless, new challenges have emerged in air pollution, such as fine aerosol particles, ground-level ozone, and benzo[a]pyrene (BaP), pollutants of which the ambient air concentration currently extensively exceeds the legal limit values, affecting 
a substantial part of the population and vast geographical regions, and the concentrations of which seem to be very difficult to decrease.

This review paper aims to address ambient air pollution in the CR in its historical perspective, collating and summarising the essential information on ambient air pollution and changes thereto, in context with its relevant negative impacts on the environment and human health over the last 70 years, i.e., from the 1950 s to the present. The review consists in three main parts covering the three principal time periods: (1) the period until the Velvet Revolution of 1989, (2) the transition period between 1989 and 2000 and (3) the modern period after 2000.

\section{Air Pollution in the Former Czechoslovakia (Prior to 1989)}

\subsection{Emission Sources and Source Areas}

Czechoslovakia's economy from the Second World War through the early 1980s grew at the expense of severe degradation of its natural sources and environment [1-3]. At that time, Czechoslovakia was a centrally planned economy under communist rule, with an emphasis on the massive development of heavy industries [4]. Ambient air pollution has been considered a major environmental threat since the 1950s. At this very time, large coal-combustion power plants were put into operation [5,6], emitting large quantities of sulphur dioxide $\left(\mathrm{SO}_{2}\right), \mathrm{TSP}, \mathrm{NO}_{\mathrm{x}}$ and other pollutants [7]. These large emission sources with high stacks (Figure 1) were concentrated in the northwest region of Bohemia (NWR, location in map in Figure 2), in the Podkrusnohori region, adjacent to the German and Polish borders in particular, where their operation was driven by local poor-quality lignite coal with extremely high sulphur and ash content [8-10].

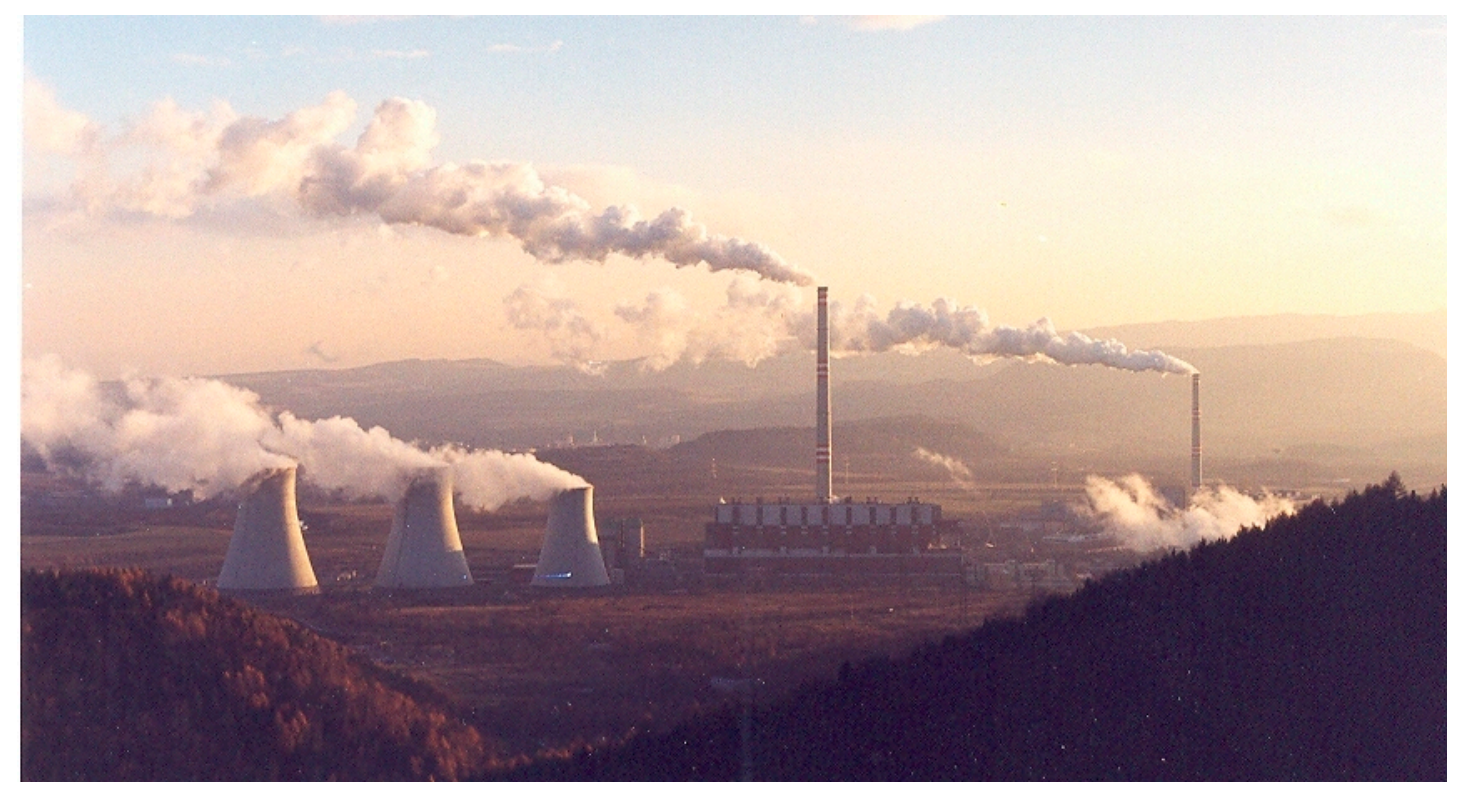

Figure 1. Prunerov coal power plant (photo by the author).

The sulphur content in the local coal varied widely according to the individual coal deposits. Coal mined in the North Bohemian Lignite Basin averaged about 1.2-3.5\%, with a maximum total sulphur content as high as $15.8 \%$ and an ash content ranging between $2.6 \%$ and $69.9 \%$ [11]. Some 50-95\% of sulphur compounds in the coal were emitted into the air [12]. The emissions were highly dependent on the applied technology and leading of the burning process [13-15]. Moreover, other trace elements potentially harmful for the environment, such as $\mathrm{As}, \mathrm{Be}, \mathrm{Pb}, \mathrm{V}, \mathrm{F}, \mathrm{Cr}, \mathrm{Cu}$ and Se were found in elevated concentrations in North Bohemian coal and released into the atmosphere while burning. The highest concentrations of As (387 ppm), Sb (7.5 ppm) and W (108.5 ppm) were reported from the Czechoslovak Army Mine (abbreviated ČSA in Czech) quarry [11]. This coal was mined in open cast mines, the 
operation of which devastated the originally scenic landscape and caused the end of numerous small settlements as well as the environmental, social and moral decline of the entire region [16-18].

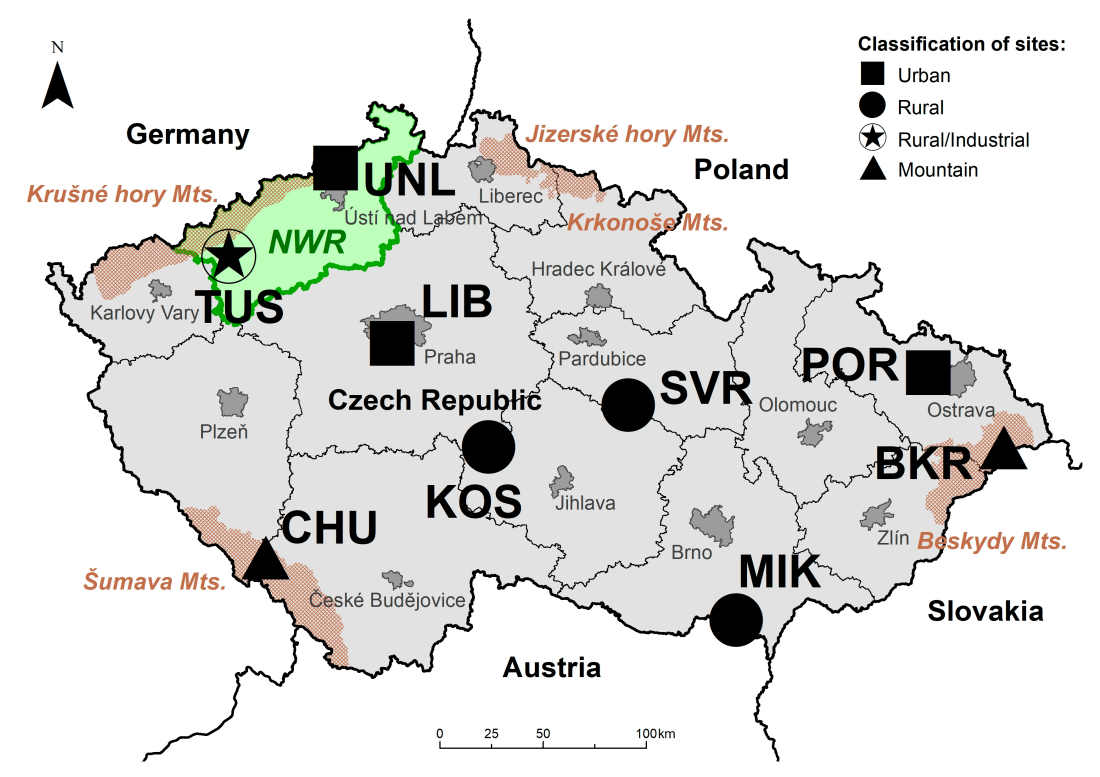

Figure 2. Map showing the areas and places mentioned in this review.

Furthermore, other industries, such as chemical, metallurgical, textile, cellulose paper mills, and glass and ceramic manufacture, added to the overall emissions [19]. The accumulation of numerous large emission sources in the poorly ventilated Podkrusnohori valley in Northwest Bohemia resulted in a poisonous air mixture, in particular during winter thermal inversions, when the ambient air pollutant levels reached extremely high values [20]. Under the communist regime, however, information on environmental, including ambient air, pollution was not available to the general population, and half-classified materials were intended exclusively as reports for experts [21]. The $\mathrm{SO}_{2}$ annual mean concentrations ranged in the order of hundreds of $\mu \mathrm{g} \mathrm{m}^{-3}$, whereas the $\mathrm{SO}_{2}$ daily mean concentrations ranged in the order of thousands of $\mu \mathrm{g} \mathrm{m}^{-3}$. The measurements at that time recorded in the unpublished internal reports of the Czech Hydrometeorological Institute (CHMI) in the above region, in particular in the adjacent Krušné hory (Mts.) (Erzgebirge, the Ore Mts.) reached up to $130 \mu \mathrm{g} \mathrm{m}^{-3}$ of $\mathrm{SO}_{2}$ in annual means during the 1970s (Figure 3). A daily mean of $1590 \mathrm{\mu g} \mathrm{m}^{-3}$ of $\mathrm{SO}_{2}$ (Figure 4) was recorded on 16 January 1982 [20]. For comparison, current ambient $\mathrm{SO}_{2}$ concentrations measured in the same region are up to $10 \mu \mathrm{g} \mathrm{m}^{-3}$ of $\mathrm{SO}_{2}$ in the annual mean [22]. The Podkrusnohori region ranked amongst the most polluted parts of the entire country [19]. Apart from the North Bohemia region, other emission source regions included the major urban areas, such as Prague (the capital), Ostrava, Pilsen, Hradec Králové and Brno, with numerous industrial enterprises and local heating systems operating on brown coal and lignite, deteriorating the ambient air quality. 


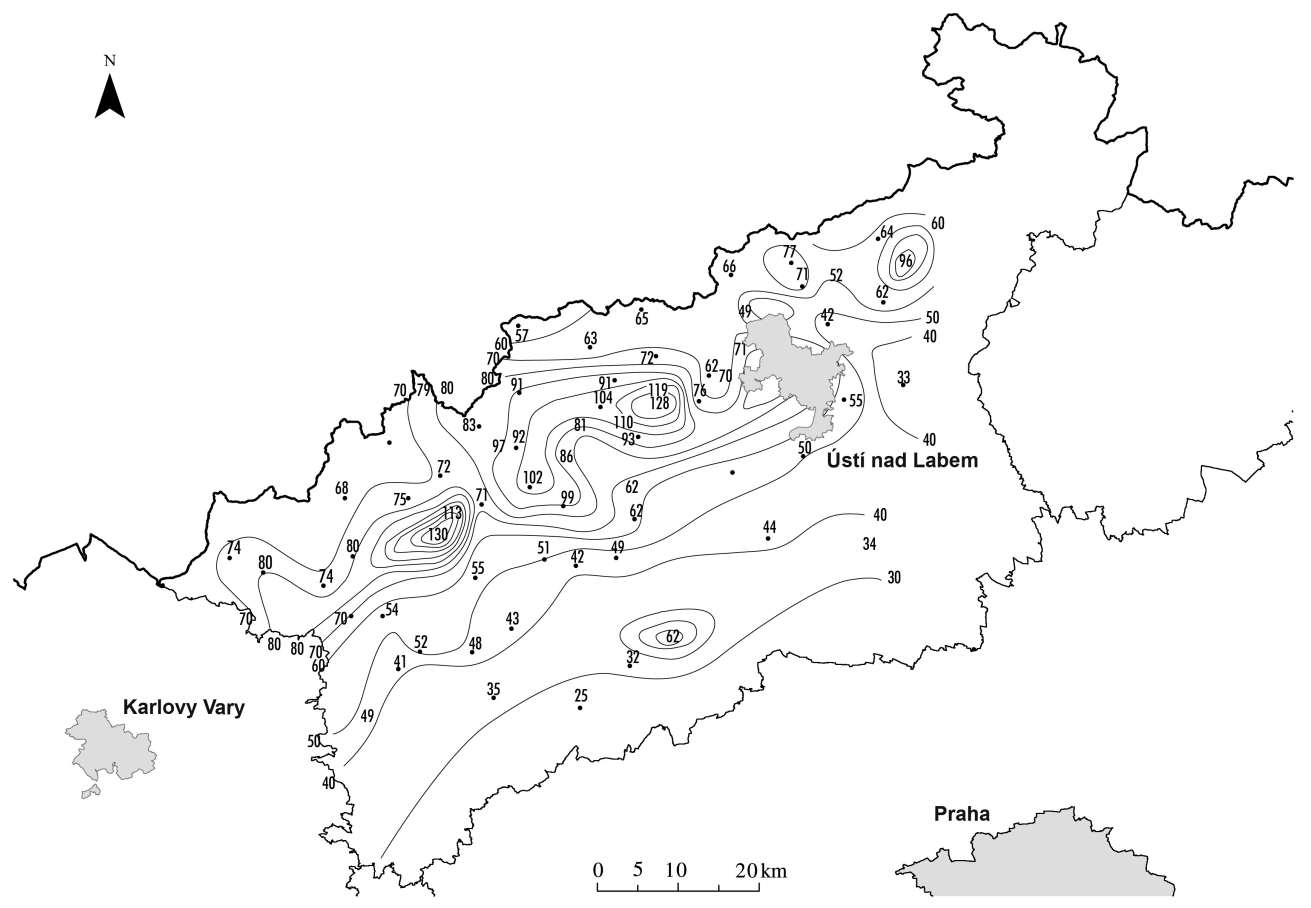

Figure 3. Map of Northwest Bohemia (NWR in Figure 2), showing the $\mathrm{SO}_{2}$ annual means in $\mu \mathrm{g} \mathrm{m}^{-3}$ in 1971-1980, the lines represent the isoconcentrations (redrawn according to [20]).

With 3150 kilotons in 1985, i.e., a full $203 \mathrm{~kg}$ per person per year in 1985, $\mathrm{SO}_{2}$ emissions in the Czech-Slovak Federal Republic (CSFR) were the highest in Europe, 2.48 times higher than in Western Europe per unit of gross national product (GNP) [23]. Further, the total $\mathrm{NO}_{\mathrm{x}}$ emissions (expressed as $\mathrm{NO}_{2}$ ) were estimated to be 1200 kilotons annually, i.e., $57 \mathrm{~kg}$ per person per year; hence Czechoslovakia took an infamous first place in $\mathrm{NO}_{2}$ emissions in Europe [23].

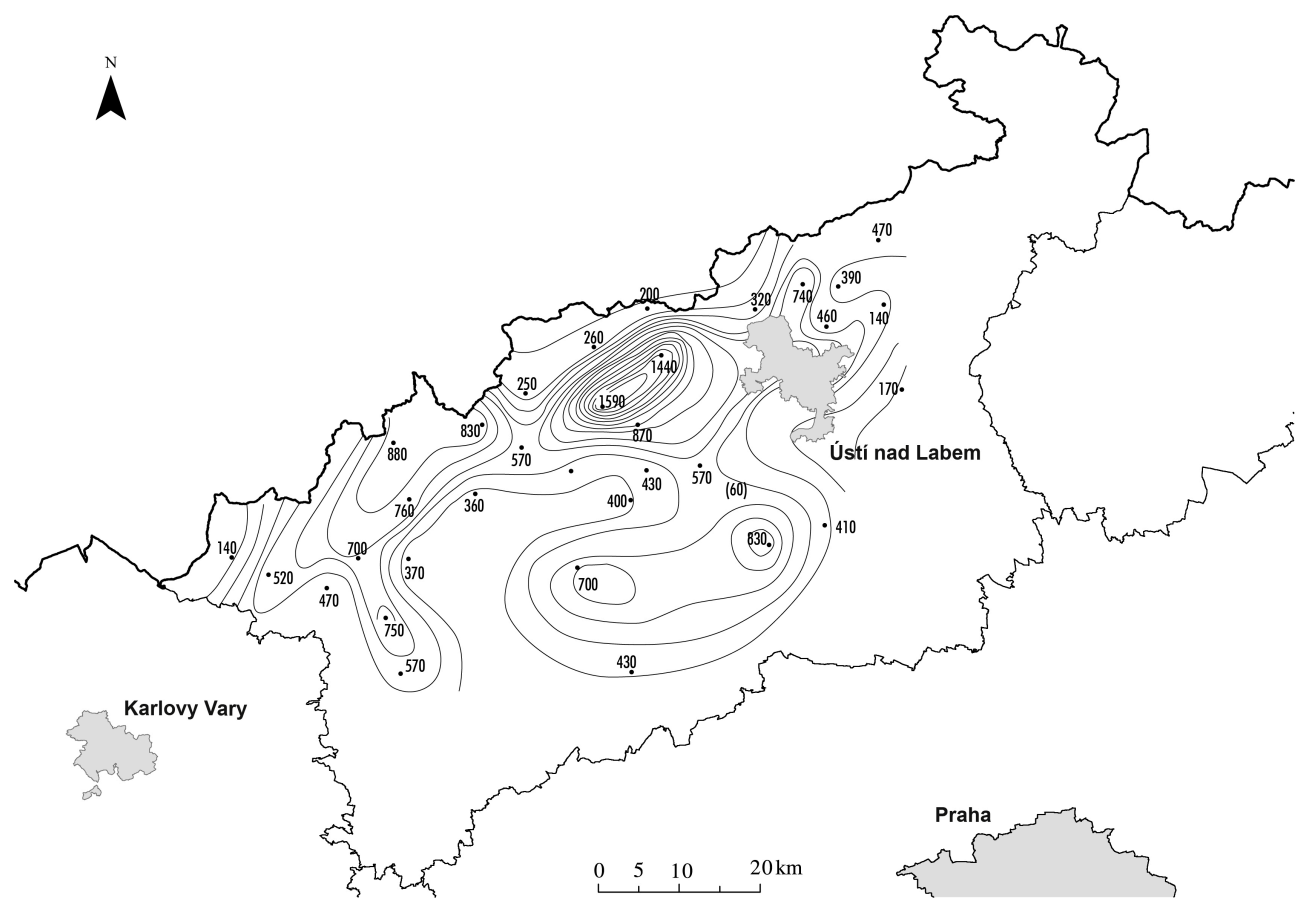

Figure 4. Map of Northwest Bohemia (NWR in Figure 2), showing the $\mathrm{SO}_{2}$ daily mean in $\mu \mathrm{g} \mathrm{m}^{-3}$ on 16 January 1982, the lines represent the isoconcentrations (redrawn according to [20]). 


\subsection{Ambient Air Quality Monitoring}

The first measurements of ambient air pollution addressed sulphur dioxide $\left(\mathrm{SO}_{2}\right)$ and total suspended particles (TSP) - the then measured total sample of aerosol without particle fraction distinction-and date back to the 1950s. The measurement activities at that time focussed on industrial and highly populated areas and ambient air pollution was observed by the Public Health Service with respect to serious human health impacts [24,25].

Regular ambient air quality monitoring has been in operation since the 1960s and individual networks were aimed at the most polluted areas. The Czech Hydrometeorological Institute (CHMI) has been responsible for nationwide ambient air quality monitoring since 1964. The first monitoring sites were situated in the Podkrusnohori region in 1968. In 1969, the network expanded to the Ostrava region and in 1970, to the Brno region [26]. Gradually, a fairly dense network was set up for monitoring $\mathrm{SO}_{2}$ in particular. Smog regulation and warning systems were built, the first was put in operation in North Bohemia in 1973 [27].

After covering the most heavily impacted regions, measurements also began in relatively unpolluted areas, far from the major emission sources, in order to gain information on regional background air pollution. The Svratouch site in the Czech-Moravian Highlands has supplied data on air quality to the worldwide Background Air Pollution Monitoring Network (BAPMON) since 1972 and to the EMEP (European Monitoring and Evaluation Programme) since 1977 [28]. In the 1980s, the Košetice site (KOS in Figure 2) was set up for environmental monitoring on a regional scale [29,30]. The air quality monitoring was supplemented by observations of precipitation chemistry, with the first site established at Hrádek u Pacova in 1974 [31].

Apart from the CHMI, several other organisations were involved in ambient air quality measurements for their own purposes, such as the Public Health Service (abbreviated in Czech as HS), Organization for the Rationalization of Power Plants (abbreviated in Czech as ORGREZ), Czech Geological Survey (abbreviated in Czech as ČGÚ, and later as ČGS), Forestry and Game Management Research Institute (abbreviated in Czech as VÚLHM), Water Management Research Institute (abbreviated in Czech as VÚV) and the Research Institute of Plant Production (abbreviated in Czech as VÚRV).

Air pollution in Czechoslovakia culminated in the 1970s and 1980s. The monitoring results from 1971-1982 for the eight most heavily impacted regions defined by the then government (i.e., North Bohemia, Mělnicko-Neratovicko, City of Prague, Hradecko-Pardubicko, Brno, West Bohemia and Pilsen) were collated by the CHMI's internal reports [20,32-38]. The incorporation of a certain area into the impacted regions was based on the annual $\mathrm{SO}_{2}$ mean concentration above $30 \mathrm{\mu g} \mathrm{m}^{-3}$ (Figure 5). Based on monitoring and dispersion modelling results, the above regions were categorised into three different air pollution levels: (1) the most polluted, which were the North Bohemia and Prague regions, (2) medium air pollution level—-the West Bohemia, Ostravsko-Karvinsko and Mělnicko-Neratovicko regions and (3) the lowest air pollution level—the Hradecko-Pardubicko and Brno regions. Interestingly, the two most polluted regions, i.e., North Bohemia and Prague, showed similar air pollution levels, though these originated from completely different emission sources. In North Bohemia, the problem arose from large emission sources, whereas in Prague the local heating systems were the culprit. Furthermore, with respect to distinct geomorphology, both Prague and the Podkrusnohori region have been prone to frequent thermal inversion occurrence preventing pollutant dispersion [39-41]. 


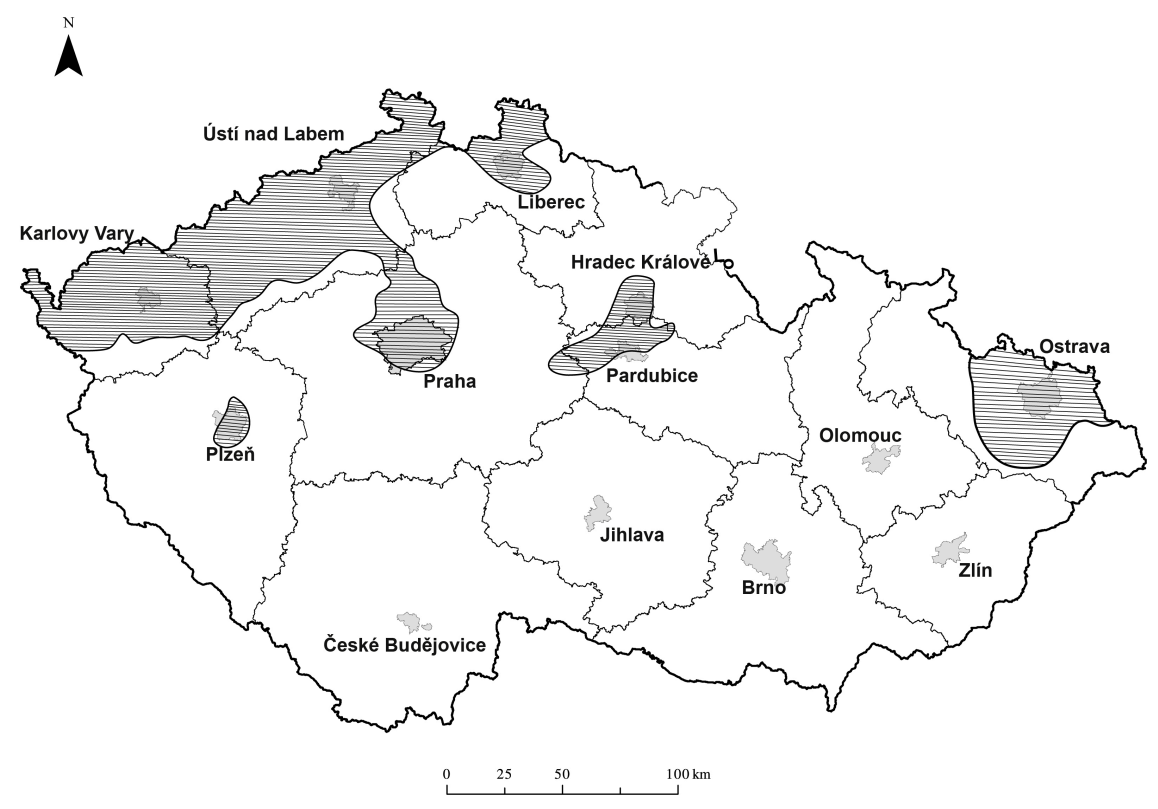

Figure 5. Map indicating the formerly impacted regions (in the 1970s and 1980s) with respect to air pollution delimited by annual $\mathrm{SO}_{2}$ mean concentration above $30 \mu \mathrm{g} \mathrm{m}^{-3}$ (redrawn according to [41]).

\subsection{Human Health Outcomes}

The first information on measured ambient air pollutant concentrations in the then Czechoslovakia, available only in Czech, originate from as early as the 1950s. They cover some industrial regions and are related to local inhabitant health outcomes [24,25]. Children living in areas with high air pollution were somewhat retarded in growth. Furthermore, they evinced significant changes in their red blood cell counts. It was recognised that children responded to elevated $\mathrm{SO}_{2}$ concentrations in similar way as to rather lower $\mathrm{O}_{2}$ pressure, such as in the high mountains: an increase in the total surface of erythrocytes ensured the transfer of $\mathrm{O}_{2}$ to tissues easier [42]. It was demonstrated that a stay of 1-3 months in a clean atmosphere had favourable effects on such children, especially with respect to the haemoglobin, and that this reaction continued for about three months after the children returned to the region with polluted air. Hence children used to be sent to an open-air school, where the air was relatively clean [42]. Air pollution belonged amongst the factors not only impairing human health but contributing even to all-cause mortality. According to Bobak and Marmot [43], an estimated 2-3\% of the total mortality could be attributed to air pollution in the CR in 1987. Bobak and Leon [44], in a study examining infant mortality and air pollution in 1986-1988 for 46 of the 85 districts of Czechoslovakia, reported a weakly positive association between neonatal mortality and ambient TSP and $\mathrm{SO}_{2}$ concentrations.

A comprehensive Teplice programme aimed at a thorough study of the impacts on human health caused by ambient air pollution, including aerosol, genotoxic organic compounds and toxic trace elements in one of most heavily impacted districts of North Bohemia [45]. A significantly higher prevalence of adverse respiratory symptoms and decreased lung function were indicated as compared to the relatively clean Prachatice district in South Bohemia [46]. Moreover, a study of the effects of exposure on pregnancy and birth revealed an excess prevalence of low birth weight and premature births [47]. Furthermore, within this study, it was indicated that air pollution may alter early childhood susceptibility to infections [48]. Exposure to intermittent air pollution in the North Bohemian Teplice district was shown to cause sperm DNA damage resulting in an increase in rates of male-mediated infertility, miscarriage, and other adverse reproductive outcomes [49].

\subsection{Environmental Issues}

Severe air pollution affected both human health and the environment. Mismanaged forest ecosystems were susceptible to additional stresses [50-57]. A substantial part of forest areas (more 
than $60 \%$ ) were damaged in various degrees by air pollution, namely $\mathrm{SO}_{2}$ acting either directly or indirectly via acid deposition and subsequent soil changes. The outcomes included increased mortality and decreased increments in forests, loss of valuable ecotypes, impact on water management and overall decrease in stability of the landscape [58-60]. Damaged forests were the most visible and best-known symptoms of acid rain [61,62]. Losses on forest wood attributable to air pollution in the then Czechoslovakia were estimated at 9.5 million $\mathrm{m}^{3}$ year ${ }^{-1}$ by the International Institute for Applied Systems Analysis (IIASA); this estimate being reckoned conservative, as exclusively $\mathrm{SO}_{2}$ was accounted for, whereas $\mathrm{NO}_{x}$ and $\mathrm{NH}_{3}$ were not considered [63]. Unprecedented forest decline, namely in the Krušné hory Mts., Jizerské hory Mts. and Krkonoše Mts., in the 1970s and 1980s were of major concern for the then foresters and forest management [64] and attracted infamous attention from scientists all over the world. The Krkonoše National Park (KRNAP) was cited-together with the adjacent Polski Park Narodowy - by the International Union for Conservation of Nature and Natural Resources (IUCN) as the world's most threatened protected natural area [65].

Though Czech environmental studies at that time were practically non-existent [21], some papers on ambient air pollution impacts on the environment can still be mentioned. Air pollution was reported to influence the nesting ecology of the house martin (Delichon urbica) in 141 villages and towns in Czechoslovakia, including a significant reduction in nesting density, colony size and occupancy [66]. Fluoride pollution in wild deer assessed in North Bohemia showed significantly decreasing exposures from the mid-1990s, attributed largely to the implementation of emission control devices on coal-fired power plants [67].

Emissions were also blamed for the contamination of crops. Ustyak and Petrikova [68] reported that the results of their study for North Bohemia in 1987-1992 indicated very high contamination of agricultural crops by heavy metals and As. Specifically, 3-16\% of fodder crop samples and $49-86 \%$ of food crop samples were contaminated (i.e., they showed higher heavy metal contents than was permissible at that time) in spite of a low degree of soil contamination. The main pollutants of fodder crops were $\mathrm{Hg}$, $\mathrm{Cd}, \mathrm{Pb}$ and $\mathrm{Co}$, whereas the main pollutants of food crops were $\mathrm{Cd}, \mathrm{Cr}, \mathrm{Hg}, \mathrm{As}, \mathrm{Pb}, \mathrm{Ni}$ and $\mathrm{Zn}$ [68].

Air pollution also affected precipitation chemistry, and consequent atmospheric deposition and stream water chemistry was observed [69]. The long-term effects of atmospheric pollution by metals and acids were documented even on sediment cores from Čertovo Lake in the Šumava Mts., situated in a relatively unpolluted region [70].

\subsection{Air Pollution in the Context of the Former Communist Countries}

The problem of severe ambient air pollution and consequent human health and environmental impacts was not limited exclusively to the former Czechoslovakia, but involved other Central European communist countries, such as the former GDR (Eastern Germany or the Democratic Republic of Germany) and Poland [71-73]. These three countries ranked among the worst polluters due to emissions from the power generation systems as well as heat production both for industry and municipalities. These sources accounted for about $90 \%$ of total $\mathrm{SO}_{2}$ emissions and about $60-70 \%$ of emissions of dust and $\mathrm{NO}_{x}$ [74]. Fly-ash emission in Eastern Europe was greater than in any other industrial region in the world [65]. The heavily industrialised 'Black Triangle' (sometimes also called the 'Dirty Triangle') region encompassing Northern Bohemia, Silesia and adjacent portions of Eastern Germany was infamous for its heavily impacted environment and the high frequency of winter smog occurrence causing an adverse effect on the health of local inhabitants and on the environment [74].

\subsection{Long-Range Transport}

A few decades ago, air pollution was considered entirely a local problem. The acceptable solution seemed to be building high stacks to disperse the emissions and thus reduce ground-level air pollutant concentrations. Due to long-range transport, however, the previously local-scale problem developed into a regional-scale issue [75]. Consequently, towards the end of the 1960s, due to the long-range transport of air pollutants, namely $\mathrm{SO}_{2}$ and $\mathrm{NO}_{x}$, a substantial decrease in $\mathrm{pH}$ of precipitation and subsequent acidification of both terrestrial and aquatic ecosystems was observed over large portions of 
Europe, including areas distant from major emissions sources, such as Norway and Sweden [76]. The problem, popularly called 'acid rain', resulted in important negative changes in chemistry and biota in lakes, running water and forests and triggered hot debates among both scientists and the general population [77-80]. The then Czechoslovakia, as a major emitter country, also contributed substantially and was blamed for air pollution export and consequent acidification problems elsewhere $[23,81]$.

\section{The Period after the Velvet Revolution, the 1990s}

Some positive trends, such as a decrease in ambient air pollution by several pollutants can be tracked back as far as the 1980s [82]. The improvement in the state of the environment, including the ambient air quality, however, has been clearly visible only since the transition from the communist past triggered by the Velvet Revolution in November 1989. In the beginning, this was due mainly to industrial decline, then later as a result of economic restructuring and privatisation $[62,83]$. In fact, the environmental issues, including the vast dissatisfaction of a considerable part of the population over the then ambient air pollution, contributed substantially to the collapse of the old regime in Czechoslovakia [84-87]. From the very beginning, a strong emphasis was therefore placed on solving environmental problems, including air pollution and the adoption of relevant countermeasures to improve the poor state of the environment [88].

As for the emissions, an unprecedented reduction in $\mathrm{SO}_{2}$ of some $90 \%$ was achieved via a combination of newly adopted strict legislation measures, considerable investments into desulphurisation remedies installed at large emission sources and a transfer from burning lignite to gas in residential heating. For comparison, the reduction in $\mathrm{SO}_{2}$ emissions in most European countries at the same time accounted for approximately $60 \%$ [89]. At the same time, TSP emissions also decreased substantially [90], whereas $\mathrm{NO}_{\mathrm{x}}$ emissions decreased considerably less [91]. An important motivation for improvements was also the preparation of the CR for accession to the EU [92]. The CR became a candidate for accession in 1993 and made all efforts to implement the EU legislation, including the Air Quality Law, well in advance.

The most pronounced improvement in a dynamic decrease in air pollutant emissions was seen in the period between 1989 and 1998 [93-95], the impetus to this favourable development being the newly set up strict emission limits to be met in 1998 (Figures 6 and 7). The existing major emission sources were forced to modernise or close up, without the exceptions abundantly permitted so far. Residential heating systems switched from burning coal to gas in many places, including Prague. A substantial reduction of residential coal consumption in the CR from 1990 to 2014 was achieved, by a factor of $6.2[96]$.

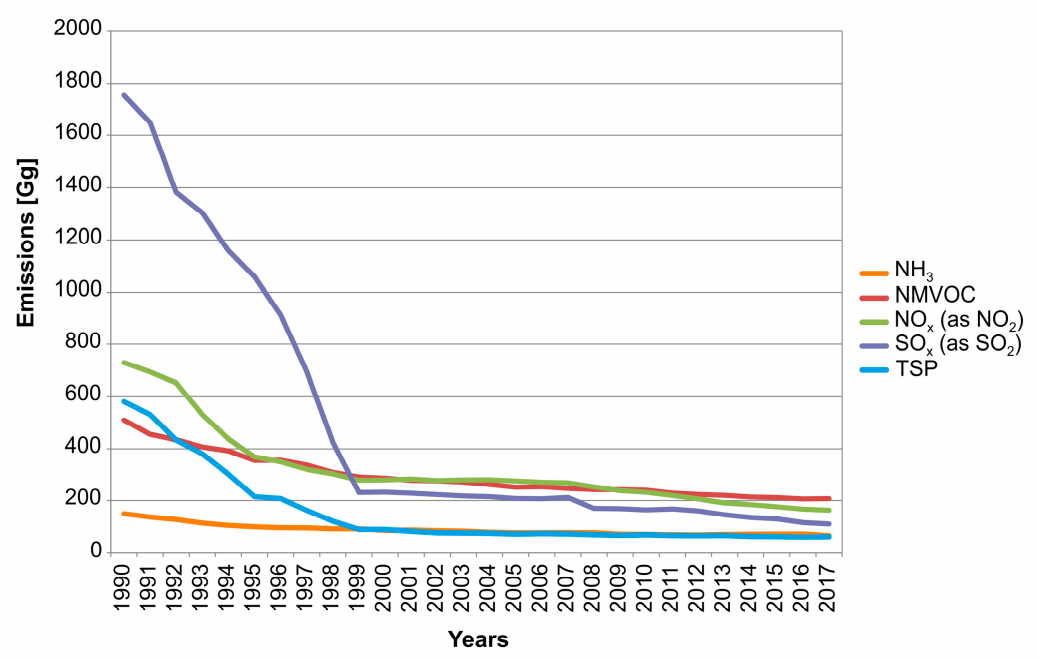

Figure 6. Overall emissions of $\mathrm{SO}_{2}, \mathrm{NO}_{\mathrm{x}}, \mathrm{NH}_{3}, \mathrm{NM}$ VOC and TSP in the Czech Republic (CR), according to European Monitoring and Evaluation Programme (EMEP) data [97]. 


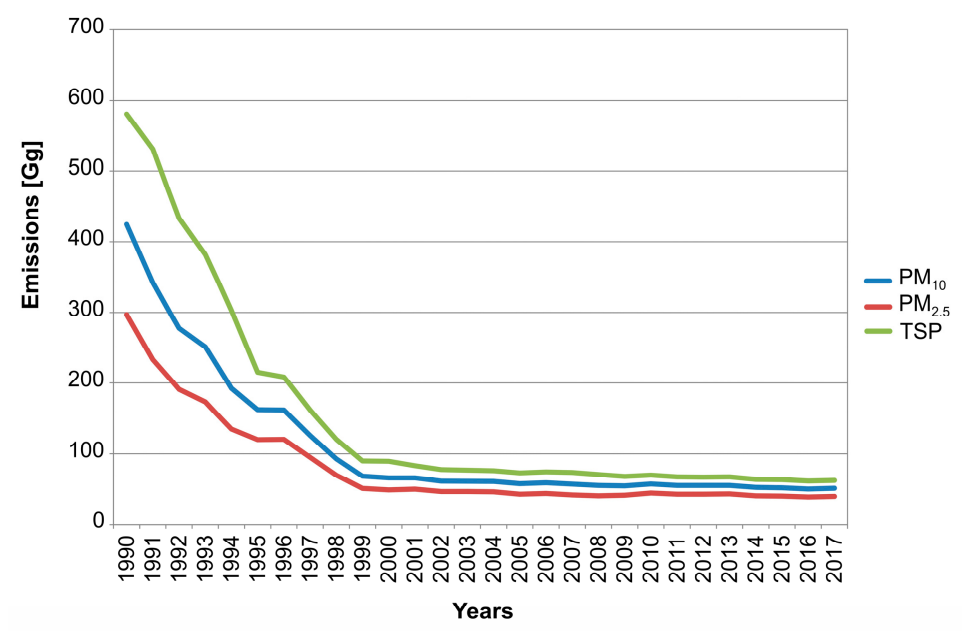

Figure 7. Overall emissions of TSP, $\mathrm{PM}_{10}$ and $\mathrm{PM}_{2.5}$ in the $\mathrm{CR}$, according to EMEP data [97].

The extent to which the changes in emissions were reflected in changes in ambient air quality is shown for several sites representing different environments, altitudes and geographical regions (Table 1, location in map in Figure 2). The trends in annual mean concentrations of $\mathrm{SO}_{2}, \mathrm{NO}_{\mathrm{x}}, \mathrm{PM}_{10}$ and $\mathrm{O}_{3}$ from the 1990s to the present time are presented in Figures 8-11. The individual annual means are missing in cases where the requirement of a sufficient number of measured values was not fulfilled [22]. The most impressive decreases, most obvious in the presented diagram for the UNL and TUS sites (both in NWR) and the Prague site LIB were recorded for $\mathrm{SO}_{2}$ (Figure 8). The ambient $\mathrm{NO}_{x}$ concentrations (Figure 9) show decreasing trends, though much milder than for $\mathrm{SO}_{2}$, with the highest concentrations for the LIB site reflecting clearly the impact of a nearby main road, and somewhat lower concentrations for the NWR sites (UNL and TUS) under influence of large thermal power plants. Fairly large differences (as compared to $\mathrm{SO}_{2}$ and $\mathrm{PM}_{10}$ ) between $\mathrm{NO}_{\mathrm{x}}$ concentrations at different types of sites are evident. Ambient $\mathrm{PM}_{10}$ concentrations (Figure 10) also show overall decreasing trends with peaks at the beginning of the 2000s. Annual means of ambient $\mathrm{O}_{3}$ concentrations (Figure 11) are not decreasing and show contrasting patterns to the above pollutants (Figures 8-10). In accordance with the general assumption, the highest values were recorded at the CHU and BKR mountain sites, whereas the lowest values were measured at the Prague LIB site.

Table 1. Measuring sites (location in map in Figure 2), the long-term records of which are presented in Figures 8-11.

\begin{tabular}{ccccc}
\hline Station & Code & Altitude [m a.s.1.] & Classification ${ }^{\mathbf{1}}$ & Region \\
\hline Ostrava-Poruba & POR & 242 & B/S/R & Ostrava \\
Mikulov-Sedlec & MIK & 245 & B/R/A-REG & South Moravia \\
Praha4-Libuš & LIB & 301 & B/S/R & Prague \\
Tušimice & TUS & 322 & B/R/IA-NCl & $\mathrm{NWR}^{2}$ \\
Ústí n.L.-Kočkov & UNL & 367 & B/S/RN & NWR $^{2}$ \\
Svratouch & SVR & 735 & B/R/N-REG & C-M Uplands \\
Bílý Kř́̌̌ & BKR & 890 & B/R/N-REG & Beskydy Mts. \\
Churáňov & CHU & 1118 & B/R/N-REG & Šumava Mts. \\
\hline
\end{tabular}

1 Classification according to the European Commission EC Decision EoI 97/101/EC: B/S/R-background/ suburban/residential, B/S/RN—background/suburban/residential, natural, B/R/IA/NCI—background/rural/industrial, agricultural/near city, B/R/A-REG— background/rural/agricultural-regional, B/R/N-REG — background/rural/natural-regional, ${ }^{2}$ NWR-Northwest region. 


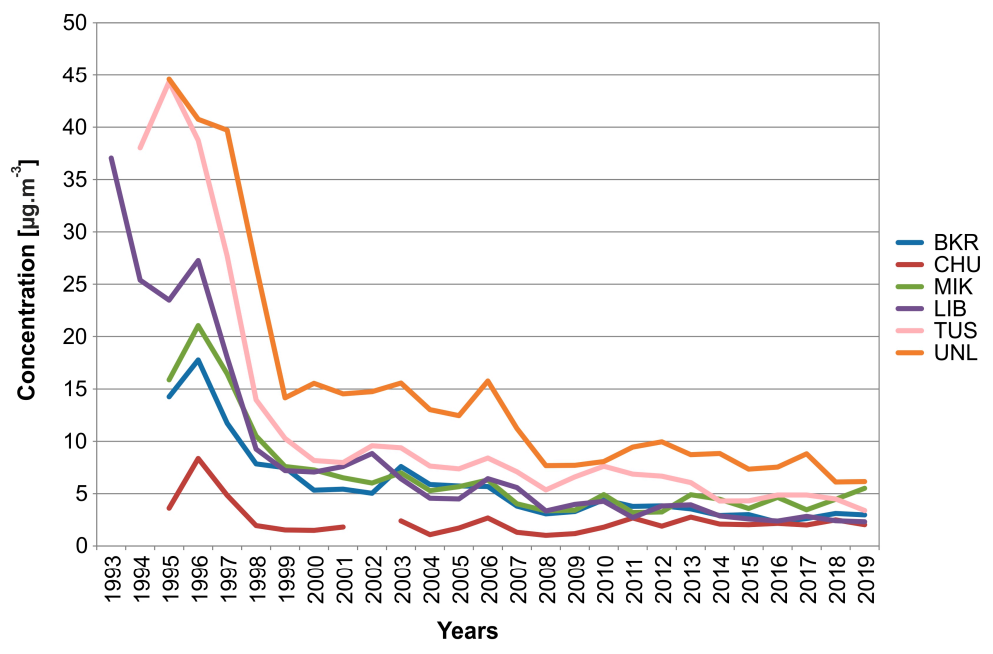

Figure 8. Trends in ambient annual mean $\mathrm{SO}_{2}$ concentrations at selected sites (see Table 1, Figure 2), 1993-2019, based on Czech Hydrometeorological Institute (CHMI) data.

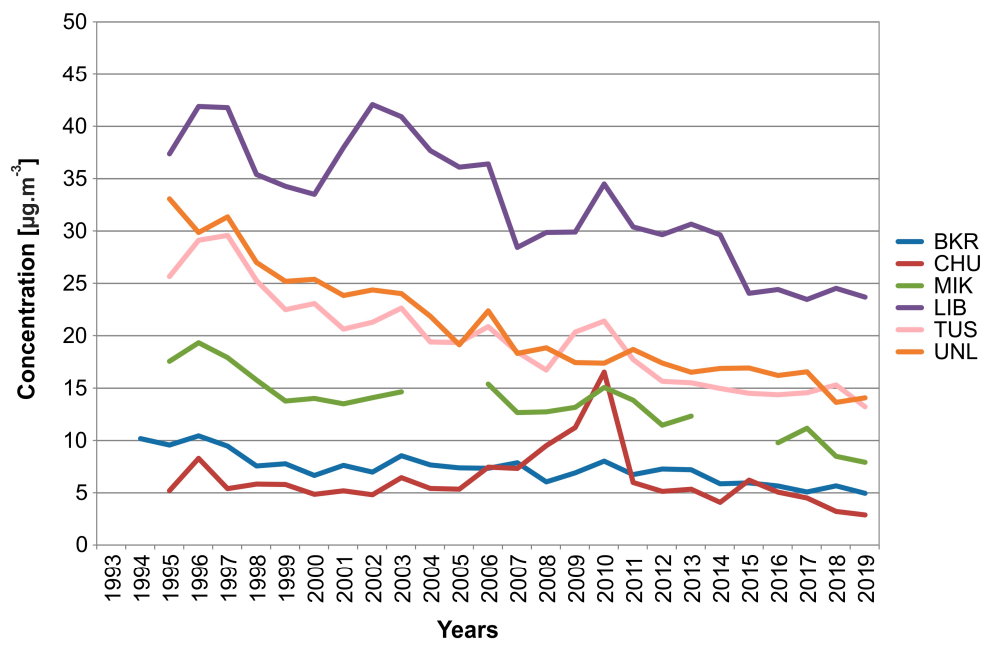

Figure 9. Trends in ambient annual mean $\mathrm{NO}_{x}$ concentrations at selected sites (see Table 1, Figure 2), 1993-2019, based on CHMI data.

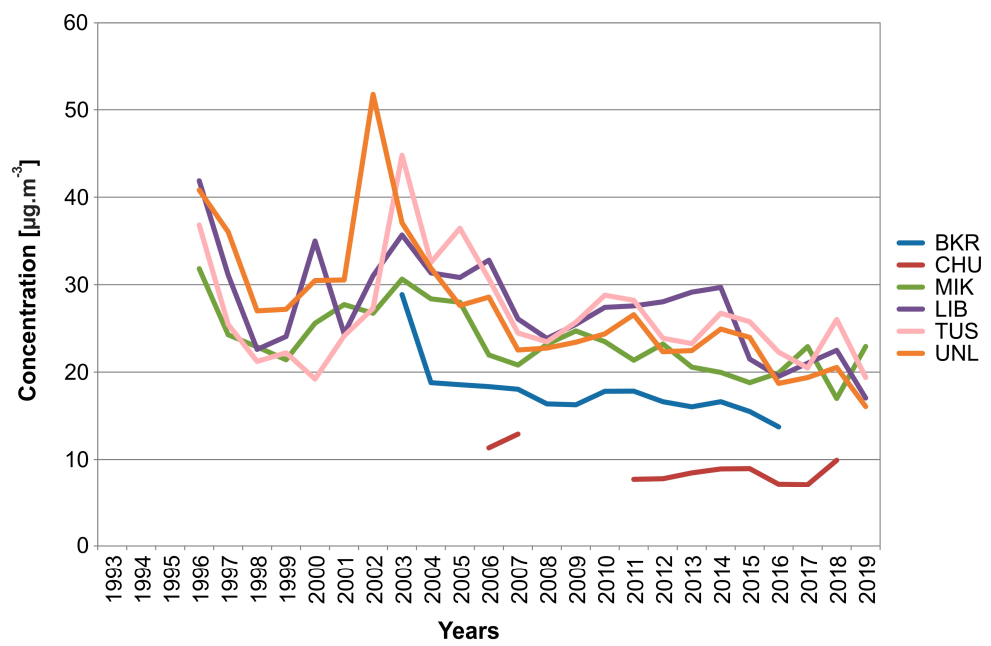

Figure 10. Trends in ambient annual mean $\mathrm{PM}_{10}$ concentrations at selected sites (see Table 1, Figure 2), 1993-2019, based on CHMI data. 


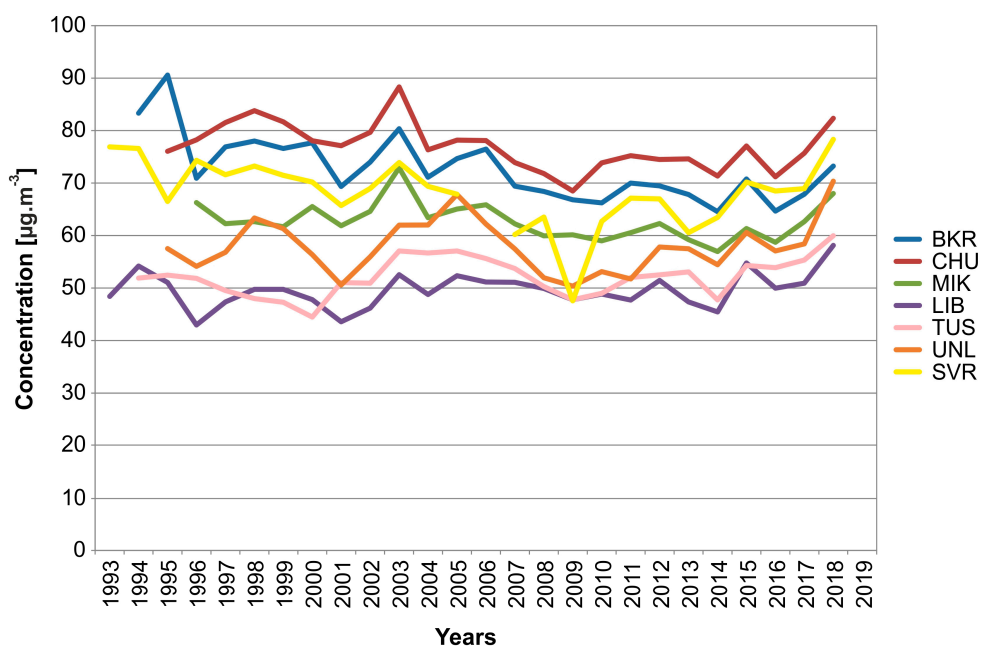

Figure 11. Trends in ambient annual mean $\mathrm{O}_{3}$ concentrations at selected sites (see Table 1, Figure 2), 1993-2018, based on CHMI data.

During the 1990s, Czechoslovakia started to be involved in various international activities, including individual studies, projects and programmes bringing numerous interesting results (e.g., [98-103]). For example, within a CAESAR (Central European Study on Air pollution and Respiratory health) study encompassing 25 study areas in six Central and Eastern European countries (Bulgaria, the Czech Republic, Hungary, Poland, Romania and the Slovak Republic), high $\mathrm{PM}_{10}$ and $\mathrm{PM}_{2.5}$ levels were indicated, with large changes between seasons, likely due to local heating. The measured PM levels were hypothesised to contribute to the observed reduced life expectancy in the region [104]. For the first time, the environment including ambient air pollution of the Czech Republic was assessed in the context of Europe's environment in the comprehensive report published by the European Environmental Agency (EEA) [105].

\section{Air Pollution in the Modern-Day Czech Republic (after 2000)}

The number of ambient air quality monitoring sites has changed continuously since 1969, the highest number of stations was in operation in the 1980s and 1990s. The optimisation of the monitoring network in the 2000s resulted in a reduction in the number of sites and the replacement of others. Currently, 198 stations in the Czech Republic monitor the air quality, 127 of which are operated by the CHMI. Of these 127 stations, 80 are automated [22].

Even though Czech ambient air quality improved substantially after 2000, the levels for some ambient air pollutants are still not satisfactory [22]. Aerosol/suspended particles, ground-level ozone and benzo[a]pyrene are considered the major problems, similarly to elsewhere in Europe [106].

The national legislation on air quality management evaluation in the Czech Republic is based on European legislation. The basic legislative norm in the CR is Act No. 201/2012 Coll., on air protection as amended ('Air Protection Act'). The ambient air quality is observed and monitored by a nationwide long-term monitoring network operated by the Czech Hydrometeorological Institute (CHMI) [22]. CHMI, an institute designated to monitor and assess the ambient air quality in the CR, focusses its activities mainly on covering the criteria pollutants, i.e., the pollutants for which limit values were set up on the basis of WHO recommendations $[107,108]$ by relevant national legislation. In accordance with EU legislation [109], these are in particular $\mathrm{SO}_{2}, \mathrm{NO}_{x}, \mathrm{PM}_{10}, \mathrm{PM}_{2.5}, \mathrm{CO}$, benzene, benzo[a]pyrene, and toxic metals in aerosol $(\mathrm{Pb}, \mathrm{Cd}, \mathrm{As}, \mathrm{Hg})$, monitored on a regular basis. Currently, due to historic reasons, the CR belongs to the countries with the densest monitoring networks [110]. Nevertheless, in accordance with legislation, the major regular monitoring activities are focused primarily on highly populated major urban agglomerations, whereas monitoring in smaller towns and communities is scarce, in spite of the fact that there are strong indications that they are highly polluted in particular 
due to local heating emissions, and in reality they are inhabited by a considerable share of the Czech population [111-113].

CHMI runs two types of stations: automated and manually operated. The automated stations measure continuously and give $1 \mathrm{~h}$ mean concentrations, whereas the manually operated stations give $24 \mathrm{~h}$ mean concentrations. Precipitation chemistry is sampled on a monthly or weekly basis by automated wet-only samplers. All the measured air quality data are stored in a central nationwide ambient air database, ISKO (the Czech acronym for the Air Quality Information System) [22]. In addition, a supersite observatory, Košetice, is run by the CHMI, participating in numerous international activities, including long-term programmes and scientific projects [114]. The regular annual reports providing detailed information on air quality are available and can be downloaded at the CHMI website [115] in Czech and English versions. The results of continuous monitoring are summarised and presented in user-friendly colour maps indicating the hotspot areas and problem regions. The results are interpreted in the context of both human health and environmental effects. Apart from these annual graphic yearbooks, long-term analyses are also available [116-118].

Furthermore, in addition to the nationwide ambient air quality monitoring run by the CHMI, numerous other measuring activities are operated by other institutes and organisations for different purposes. These include, e.g., the monitoring of persistent organic pollutants (POPs), which are not explicitly included among the criteria pollutants but are widely recognised as extremely harmful substances (due to their persistency and bioaccumulation) on human health [119-123]. In addition to direct measurement, tree needles and mosses were proven to be useful monitors giving similar information on POPs as high-volume air monitoring [124,125].

With regard to aerosol, not only lawful mass concentration, but also particle number concentration (particle number size distribution) is measured, suitable in particular for aerosol dynamics and source apportionment studies [126-128]. In addition, the main fractions of carbonaceous aerosols, i.e., organic carbon (OC) and elemental carbon (EC) are measured in both urban and rural areas [129,130].

\subsection{Aerosol}

Aerosol, or suspended particles, is considered to be a major air pollution problem in the CR, similarly to elsewhere [106]. According to the latest annual report [22] providing an assessment of ambient air quality based on established limit values [109], in 2018, the daily limit value of $50 \mu \mathrm{g} \mathrm{m}^{-3}$ for $\mathrm{PM}_{10}$ was exceeded over $3.2 \%$ of the entire territory of the $\mathrm{CR}$ (in a grid of $1 \times 1 \mathrm{~km}$ ) inhabited by approximately $14 \%$ of the population; the annual limit value of $40 \mu \mathrm{g} \mathrm{m}^{-3}$ for $\mathrm{PM}_{10}$ was exceeded at $0.1 \%$ of the entire territory of the $\mathrm{CR}$ with approximately $0.3 \%$ of the population. The annual limit value of $25 \mu \mathrm{g} \mathrm{m}^{-3}$ for fine fraction of $\mathrm{PM}_{2.5}$ was exceeded in $1.2 \%$ of the entire territory of the CR inhabited by approximately $6.1 \%$ of the population. The annual limit value of $1 \mathrm{ng} \mathrm{m}^{-3}$ for benzo[a]pyrene, an established human carcinogen $[131,132]$ related to $\mathrm{PM}_{2.5}$ aerosol fraction and indicator of polycyclic aromatic hydrocarbons (PAHs) exposure, was exceeded in a number of cities and municipalities, on $12.6 \%$ of the entire CR territory inhabited by an astounding 35.5\% of the country's inhabitants [22]. The trends in $\mathrm{BaP}$ based on long-term monitoring by the CHMI at several suburban sites, representing the exposure in residential areas of Czech cities in 2004-2018 are presented in Figure 12.

With respect to PAHs as a group, a study [133] measuring 15 PAHs (including seven which are carcinogenic) in $\mathrm{PM}_{1}$ in the winters of 2013 and 2017 in industrial, urban and rural sites indicated values ranging between $60.8 \mathrm{ng} \mathrm{m}^{-3}$ (in the city of Ostrava) and $11.7 \mathrm{ng} \mathrm{m}^{-3}$ (in the small town of Čelákovice). The burning of biomass and coal used for residential heating in old-style boilers emits high PaH concentrations in particular [134]. PAH concentrations linked to local heating, as one of the important sources, were also found at the National Atmospheric Observatory Košetice (NAOK), a rural background site in the CR [135]. Particle-bound carcinogenic PAHs concentration may be applied as an indicator for estimation of the biologically active (mutagenic, genotoxic, embryotoxic) components used for epidemiological studies of the effects of air pollution on human health [136]. 


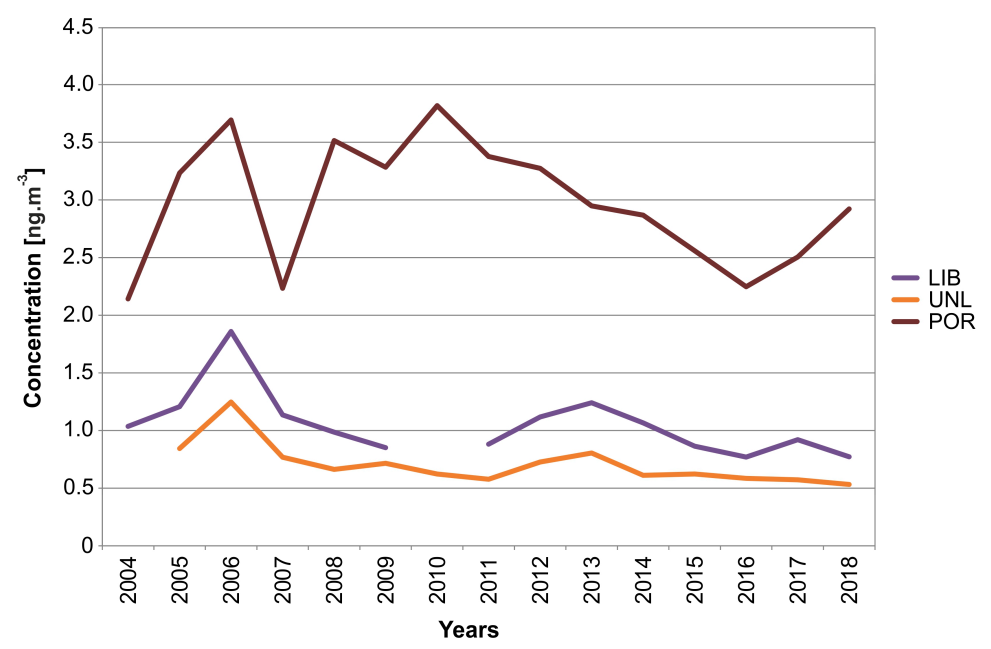

Figure 12. Trends in ambient annual mean $\mathrm{BaP}$ concentrations at selected sites (see Table 1, Figure 2), 2004-2018, based on CHMI data.

Due to long-term monitoring results, the Moravian-Silesian region/Ostrava region is recognised not only as a Czech hotspot for PM and BaP, but also truly as a European hotspot [22,106]. Ambient $\mathrm{BaP}$ concentrations frequently exceed the limit value of $1 \mathrm{ng} \mathrm{m}^{-3}$ at some sites of this region by seven to nine times [22]. The Ostrava region, with its concentrated heavy industry was in the past nicknamed the steel heart of the country. The heavy air pollution in this region results from several major sources, such as traditional steel and coke plants, local heating (with common burning of waste or coal powder) and traffic and, last but not least, by regional transport of polluted air masses from industrial parts of Poland [137-143]. Industry is apparently the major source of ultrafine particles (UFP) [144,145], the aerosol fraction which is blamed for the strongest effects on human health [146].

The local heating systems in Czech towns and villages burning either coal or wood also contribute substantially to PM exposures [111-113,147-149]. It is estimated that nearly $20 \%$ of the households in the CR are heated individually by the combustion of solid fuels [150]. That wood burning might be a dominant source of $\mathrm{PM}_{10}$ mass followed by coal combustion was somewhat surprisingly demonstrated even for the residential section of Mladá Boleslav, an industrial town famous for its large Skoda automotive factory [151]. Moreover, an incorrectly led combustion process [152], including the co-combustion of fuel with municipal waste, which is a common (though banned) practise in some regions (in particular with low-income residents who use this practise due to economic reasons), adds substantially to both PM and BaP emissions [153]. Currently, a programme subsidising the change of old types of manually operated boilers, which do not meet the emission requirements of European legislation [154] is under way, promoted and supported by the Ministry for the Environment.

All kinds of transport add substantially to this pollution and road vehicles in some places might even be the principal source of aerosol, such as in Prague, with a still unfinished city bypass and the major roads crossing the very centre of the city $[155,156]$. The hotspots are to be found in particular at places along the main roads, as was shown, e.g., in a study aimed to quantify the UFP exposure in the breathing zone in residential neighbourhoods of streets [157].

Serious health outcomes, including genotoxicity, due to the permanent high ambient PM and $\mathrm{BaP}$ exposures were reported for the Ostrava region by several studies conducted recently [158-163]. Furthermore, a moderately strong association between air pollutant concentrations and respiratory difficulties among asthmatic children and adolescents was reported [164]. The association between particle number and $\mathrm{PM}_{2.5}$ concentrations and daily hospital admissions due to cardiovascular and respiratory diseases was reported for Prague [165]. A long-term study of the health impacts of air pollution on children in heavily polluted parts of the CR revealed that air pollution significantly affected children's health and resulted in increased respiratory morbidity [166,167]. 


\subsection{Ground-Level Ozone}

Ground-level $\mathrm{O}_{3}$, recognized as an air pollutant only recently, has been monitored in the $\mathrm{CR}$ since 1993. Though emissions of $\mathrm{O}_{3}$ precursors have decreased substantially $\left(\mathrm{NO}_{\mathrm{x}}, \mathrm{VOC}\right.$ and $\mathrm{CO}$ by approximately one half and $\mathrm{CH}_{4}$ by one quarter in the $\mathrm{CR}$ and in neighbouring countries), no corresponding decrease in $\mathrm{O}_{3}$ ambient levels has been observed. In a thorough time trend analysis of continuous data from 26 long-term monitoring sites of various types (urban, mountain, rural) reflecting different environments in 1994-2015, statistically significant decreasing trends were recorded only at about one-half of these [117]. The fact that $\mathrm{O}_{3}$ concentrations show high year-to-year variability due to their strong dependence on meteorological conditions of the specific year [168-170] was demonstrated also on the Czech data [171]. Both meteorology and air pollution (precursor emissions) are responsible for day-to-day variability in $\mathrm{O}_{3}$ concentrations. This was shown for five $\mathrm{Czech}$ rural sites representing middle-elevated forests in Central Europe, where daily $\mathrm{O}_{3}$ levels were significantly associated with air temperature, global solar radiation, relative humidity and ambient $\mathrm{NO}_{x}$ concentrations, the association being highly non-linear [172]. The phytotoxic potential of $\mathrm{O}_{3}$, expressed by exposure index for forests AOT40F-a measure of potential effects as used throughout Europe [173] —is high for most of the CR $[110,174,175]$. The highest AOT40F values observed reached 38-39 ppm h; and the critical level for forest protection of $5 \mathrm{ppm} h$ is usually exceeded early in the growing season, generally in May, at most of the measuring sites [176]. The $\mathrm{O}_{3}$ spatial exposure pattern correlates strongly with the map showing global solar radiation across the $\mathrm{CR}$ [177]. The highest $\mathrm{O}_{3}$ exposures are found in the relatively unpolluted, with respect to other pollutants, southern portions of the $\mathrm{CR}$ [172]. The $\mathrm{O}_{3}$ concentrations increase with the altitude, whereas the increase of AOT40 with rising altitude is less clear [178].

Apart from long-term monitoring sites, measuring pollution continuously using the reference method as declared by the EU, as well as standard Quality Assurance/Quality Control (QA/QC) procedures (EC, 2008), for developing more detailed $\mathrm{O}_{3}$ spatial patterns in more detailed scales, diffusive (passive) samplers were used. According to recommendations given by Krupa and Legge [179], these were used for indicative measurements within environmental studies conducted in protected natural areas (the Jizerské hory Mts., Orlické hory Mts., Novohradské hory Mts. and České Švýcarsko National Park), in complex, less accessible terrain in forested mountain areas without electricity available for standard measurements, and proved very successful, offering high precision and accuracy [180-183].

To date, published papers on the $\mathrm{O}_{3}$ biological effects on Czech forests are ambiguous [183-188]. However, despite the fact that the recorded $\mathrm{O}_{3}$ concentrations are fairly high, no serious harmful effects attributable to $\mathrm{O}_{3}$ have been published so far. This conclusion, i.e., that there is no clear field evidence in forests under high $\mathrm{O}_{3}$ concentrations in the $\mathrm{CR}$, corresponds with similar reports from studies conducted throughout Europe (e.g., [189]).

In contrast to environmental studies, epidemiological studies indicated clear $\mathrm{O}_{3}$ impacts on human health. In a five-year study (2002-2006) in Prague, including the 2003 and 2006 ozone abundant summer seasons, a statistically significant association between $\mathrm{O}_{3}$ levels and daily mortality from respiratory diseases was revealed [187]. A relative risk of 1.080 (95\% CI: 1.031-1.132) was observed for mortality from respiratory diseases per $10 \mu \mathrm{g} \mathrm{m}^{-3}$ increase in 1 day lagged daily mean $\mathrm{O}_{3}$ concentrations, which acknowledged that $\mathrm{O}_{3}$ exposure in Prague, though lower when compared to many other European cities, is high enough to influence human health adversely [190]. This factor should be examined more with respect to climate change with an increasing frequency of extreme weather, including heat waves [191].

\subsection{Atmospheric Deposition}

Atmospheric deposition, as an important self-cleaning process of the atmosphere, removes air pollutants from the air on one hand, while on the other hand it acts as a contamination source for other spheres, such as the hydrosphere, pedosphere and biosphere [170]. The long-term monitoring results have shown a significant decrease in sulphur deposition at most measuring sites $[94,116,192]$. The spatial pattern of changes in sulphur deposition fluxes between 1995 and 2011 revealed a decrease 
over forested areas in a wide range of 18.1 to $0.2 \mathrm{~g} \mathrm{~m}^{-2}$ year $^{-1}$ with the highest improvement in the formerly most heavily impacted areas [116]. In contrast, nitrogen deposition has not improved much, and its spatial patterns are far more complex. The highest decrease in $\mathrm{N}$ deposition flux between 1995 and 2011 was a mere $2.5 \mathrm{~g} \mathrm{~m}^{-2}$ year $^{-1}$ in the formerly most heavily impacted areas, a stagnation in Southern and Northern Moravia and a mild increase of $0.4 \mathrm{~g} \mathrm{~m}^{-2}$ year ${ }^{-1}$ in the Jizerské Mts., close to the Polish and German borders [116]. The trends in air pollutant emissions are reflected in changes in atmospheric chemistry and deposition, including changing proportions of the ion ratios of $\mathrm{NO}_{3}{ }^{-} / \mathrm{SO}_{4}{ }^{2-}$, $\mathrm{NH}_{4}{ }^{+} / \mathrm{SO}_{4}{ }^{2-}$ and $\mathrm{NH}_{4}{ }^{+} / \mathrm{NO}_{3}$ - in precipitation [94,116,193].

Similarly as in other regions of Europe and US [194,195], it was demonstrated that in the CR, by not considering (1) deposition path via fog and (2) unmeasured constituents of dry deposition, such as $\mathrm{NH}_{3}$ and $\mathrm{HNO}_{3}(\mathrm{~g})$, the total sulphur and nitrogen depositions are likely to be underestimated substantially $[196,197]$. Although the chemistry of fog is regularly observed at only a few sites in the CR, and information on fog chemistry is scarce $[198,199]$, it is widely recognised that fog in the CR is enriched as compared to rain, particularly in $\mathrm{SO}_{4}{ }^{2-}$ and $\mathrm{NO}_{3}{ }^{-}[103,104,200]$. Moreover, the hydrological input of fog, namely in forested mountain areas, in the CR above $800 \mathrm{~m}$ above sea level might not be negligible [201]. $\mathrm{SO}_{2}$ and $\mathrm{NO}_{x}$, precursors of $\mathrm{SO}_{4}{ }^{2-}$ and $\mathrm{NO}_{3}{ }^{-}$in fog, were shown to be (apart from the relative humidity) significant explanatory variables modelling the fog probability at Czech sites [202]. The fog pathway should definitely be accounted for in real deposition flux studies, although fog occurrence in the CR has decreased significantly over the last sixty years [203]. The chemistry of rime (as a part of horizontal deposition) has been studied recently at 10 regional mountain-top sites in the CR [204-207], nevertheless the contribution of rime to atmospheric deposition has been unclear thus far.

Improving ambient air quality and decreasing atmospheric deposition have also been demonstrated by long-term nationwide biomonitoring, including analyses of mosses and tree bark [208-213]. Furthermore, peat bogs proved useful for reflecting the history of heavy metal atmospheric deposition. An analysis of historical rates of $\mathrm{Pb}$ deposition over the past $150-200$ years using ${ }^{210} \mathrm{~Pb}$ dated in sphagnum-derived peat cores peaking in 1965-1992 confirmed a period of the highest production and burning of local lignite [214]. Peaks in $\mathrm{Hg}$ accumulation rates in peat cores were indicated between the 1950s and 1980s, reflecting the emissions from intensive coal burning in Central Europe [215]. Moreover, tree rings can be used as an archive for air pollution as was demonstrated for the $\mathrm{Pb}$ and ${ }^{206} \mathrm{~Pb} /{ }^{207} \mathrm{~Pb}$ ratio [216]. A decrease in arsenic deposition for the Orlické hory Mts. (Adlergebirge) near the Czech-Polish border in the winters of 1984-1986 and 2003-2015 was reported by Doušová et al. [217].

Recovery from acid deposition with respect to changes in soil, stream water and lake water chemistry was reported from numerous places in the $\mathrm{CR}$ after the $\mathrm{SO}_{2}$ and $\mathrm{NO}_{\mathrm{x}}$ emission reduction in Central Europe [218-222]. Nevertheless, in spite of a certain N deposition decrease, it was indicated that Czech forest soil horizons up to $20 \mathrm{~cm}$ in depth are still affected by a high $\mathrm{N}$ input [223], and in some regions elevated $\mathrm{N}$ deposition results in soil nutrient imbalances, in particular between nitrogen and phosphorus and nitrogen and magnesium [224]. Consequently, a higher proportion of nitrophilous species was detected in Czech forests during recent decades [225]. It was shown that a high acidic deposition, apart from geographical variables affects the climate-growth association of Picea abies, the most important tree species in the CR [226,227].

\section{Conclusions}

This review presents the ambient air quality development over the last 70 years in the territory of the modern-day Czech Republic. Major activities and achievements in ambient air quality management are indicated. The long-term nationwide monitoring results are supplemented by goal-directed one-time studies. Furthermore, apart from the air quality itself, the ambient air pollution impacts on both human health and the environment are collated.

It is obvious that much has been done in air pollution prevention, and that ambient air quality in the CR has improved substantially over the period under review due to newly introduced stringent 
legislation and technical countermeasures. Nevertheless, there are still activities which remain significant emission sources, such as local heating and vehicle transport travelling through communities, which are political issues that are hard to manage. The share of the population permanently exposed to $\mathrm{PM}$ and $\mathrm{BaP}$ concentrations above limit values remains considerable, and $\mathrm{O}_{3}$ exposure for both humans and the environment is of high concern. Furthermore, despite significant emission reduction, atmospheric deposition, in particular of nitrogen, remains high in some regions.

Long-term ambient air quality monitoring has generated a vast database, which is still, in spite of numerous published studies, largely unexplored. This invaluable source of information should be examined more thoroughly. An association of historical and modern-day results might be one of the interesting goals for future analysis, offering a new perspective. Moreover, the ambient air quality data offer a unique input for large environmental studies and models, exploring in detail how air pollution affects the biosphere and hydrosphere, including forest, agricultural, natural and water ecosystems.

Funding: Open Access and Article Processing Charge was funded by the Czech Hydrometeorological Institute research project “Dlouhodobá koncepce rozvoje výzkumné organizace (DKRVO) Český hydrometeorologický ústav na období 2018-2022" financed by the Czech Ministry of Environment.

Acknowledgments: I would like to thank Petra Tichá and Jana Schovánková, both from the Czech Hydrometeorological Institute, for preparing Figure 2, Figure 3, Figure 4, Figure 5, Figure 6, Figure 7, Figure 8, Figure 9, Figure 10, Figure 11and Figure 12 and Erin Naillon for proofreading of this manuscript.

Conflicts of Interest: The author declares no conflict of interest.

\section{References}

1. Mejstř́k, V. Air pollution and some aspects of the ecotoxicological situation in Czechoslovakia. Sci. Total Environ. 1993, 134 (Suppl. 1), 207-215. [CrossRef]

2. Mikoláš, J. Environment in Czechoslovakia: Today and Tomorrow. In Strategisches Management Global; Hammer, R.M., Hinterhuber, H.H., Kutis, P., Turnheim, G., Eds.; Gabler Verlag: Wiesbaden, Germany, 1993; Available online: http://link.springer.com/chapter/10.1007/978-3-322-89350-5_8 (accessed on 10 September 2019).

3. Kuskova, P.; Gingrich, S.; Krausmann, F. Long term changes in social metabolism and land use in Czechoslovakia, 1830-2000: An energy transition under changing political regimes. Ecol. Econ. 2008, 68, 394-407. [CrossRef]

4. Kovanda, J.; Hak, T. Historical perspectives of material use in Czechoslovakia in 1855-2007. Ecol. Indic. 2011, 11, 1375-1384. [CrossRef]

5. Staller, G.J. Czechoslovak Industrial Growth: 1948-1959. Am. Econ. Rev. 1962, 52, 385-407.

6. Valášek, V.; Chytka, L. Velká Kronika o Hnědém Uhlí: Minulost, Současnost a Budoucnost Těžby Hnědého Uhli v Severozápadních Čechách (Large Chronicle on Brown Coal: The Past, Present and Future of Brown Coal Mining in North-West Bohemia), 1st ed.; G2 Studio: Plzen, Czech Republic, 2009; In Czech.

7. Rubin, E.S. An International Perspective. J. Air Pollut. Control Assoc. 1981, 31, 349-360. [CrossRef]

8. Kapička, A.; Petrovský, E.; Ustjak, S.; Macháčková, K. Proxy mapping of fly-ash pollution of soils around a coal-burning power plant: A case study in the Czech Republic. J. Geochem. Explor. 1999, 66, $291-297$. [CrossRef]

9. Bouška, V.; Pešek, J. Quality parameters of lignite of the North Bohemian Basin in the Czech Republic in comparison with the world average lignite. Coal Geol. 1999, 49, 211-235. [CrossRef]

10. Chow, C.-L. Sulfur in coals: A review of geochemistry and origins. Int. J. Coal Geol. 2012, 100, 1-13. [CrossRef]

11. Pešek, J.; Sivek, M. Uhlonosné Pánve a Ložiska Černého a Hnědého Uhlí České Republiky (Coal Basins and Deposits of Black and Brown Coal in the Czech Republic); ČGS: Praha, Czech Republic, 2012; In Czech.

12. Kurfürst, J. Reasons and measures for reducing sulfur dioxide emission. Ochr. Ovzdusi 1986, 18, 3-6.

13. Bretschneider, B.; Kurfürst, J. Air Pollution Control: Technology; Elsevier: Amsterdam, The Netherlands, 1987.

14. Stehlík, J. Dominantní Příčiny Znečišt’ování Ovzduší: Spalovací Procesy. (Principal Reasons for Air Pollution: Combustion Processes). In Kompendium Ochrany Ovzduší; Kurfurst, J., Ed.; Ekomonitor: Chrudim, Czech Republic, 2008; In Czech. 
15. Kurfürst, J.; Musil, Z. Technické prostředky omezování emisí (Technologies for Emission Abatement). In Kompendium Ochrany Ovzduší; Kurfürst, J., Ed.; Ekomonitor: Chrudim, Czech Republic, 2008.

16. Moldan, B.; Schnoor, J.L. Czechoslovakia-Examining a Critically Ill Environment. Environ. Sci. Technol. 1992, 26, 14-21. [CrossRef]

17. Ř́ha, M.; Stoklasa, J.; Lafarová, M.; Dejmal, I.; Marek, J.; Pakosta, P. The Environmental Mining Limits in the North Bohemian Lignite Region; Společnost Pro Krajinu: Prague, Czech Republic, 2011; p. 64.

18. Frantál, B.; Nováková, E. A Curse of Coal? Exploring Unintended Regional Consequences of Coal Energy in the Czech Republic. Morav. Geogr. Rep. 2014, 22, 55-65. [CrossRef]

19. Carter, F.W. Pollution problems in post-war Czechoslovakia. Trans. Inst. Br. Geogr. 1985, 10, 17-44. [CrossRef]

20. Hrdá, J. (Ed.) Znečištění Ovzduší v Severočeské Oblasti (Ambient Air Pollution in North Bohemia); Výzkumná Zpráva za Úkol P 16-331-453; ČHMÚ: Praha, Czechoslovakia, 1982; In Czech.

21. Nondek, L. Czechoslovak environment. Nature 1991, 354, 180. [CrossRef]

22. CHMI. Air Pollution in the Czech Republic in 2018; Graphical Yearbook (Czech/English); Czech Hydrometeorological Institute: Prague, Czech Republic, 2019.

23. Stoklasa, J. Environmental Problems in the CSFR: Solutions Through International Cooperation. In Coping with Crisis in Eastern Europe's Environment; Alcamo, J., Ed.; IIASA: Lancs, UK, 1992; Available online: http://pure.iiasa.ac.at/id/eprint/3585/1/XB-92-005.pdf\#page=139 (accessed on 4 November 2019).

24. Krásná, V. Některé poznatky ze studia znečištění pražského ovzduší a jeho vlivu na zdravotní stav obyvatelstva (Some findings from examination of Prague's ambient air and its impact on the human health of Prague's inhabitants). Československá Hygiena 1960, 5, 77-88. (In Czech)

25. Symon, K. Znečištění ovzduší a jeho vztah ke zdravotnímu stavu obyvatelstva (Ambient air pollution and its relation to human health). Československá Hygiena 1960, 5, 72-79. (In Czech)

26. Böhm, B. Znečištění Ovzduší v Podkrušnohoří (Ambient Air Pollution in the Podkrusnohori Region); Sborník Prací 20; HMÚ: Praha, Czechoslovakia, 1974; In Czech.

27. Bubník, J.; Keder, J. Prognózní a signální systémy ochrany ovzduší v ČSR (Forecasting and signal systems of air quality protection in the CSR). Meteor. Zpr. 1986, 39, 169-171.

28. Torseth, K.; Aas, W.; Breivik, K.; Fjaeraa, A.M.; Fiebig, M.; Hjelbrekke, A.G.; Myhre, C.L.; Solberg, S.; Yttri, K.E. Introduction to the European Monitoring and Evaluation Programme (EMEP) and observed atmospheric composition change during 1972-2009. Atmos. Chem. Phys. 2012, 12, 5447-5481. [CrossRef]

29. Böhm, B. Výzkum regionálního znečištění některých hlavních složek přírodního prostředí (Research of regional pollution of the natural environment). Meteor. Zpr. 1986, 39, 136-139.

30. Böhm, B.; Gürtlerová, P. Pozorování na regionální stanici GEMS v Košeticích (Observations at the GEMS regional station in Košetice). Meteor. Zpr. 1986, 39, 175-180.

31. Moldan, B.; Veselý, M.; Bartoňová, A. Chemical composition of atmospheric precipitation in Czechoslovakia, 1976-1984-I. Monthly samples. Atmos. Environ. 1987, 21, 2383-2395. [CrossRef]

32. Hrdá, J. Znečištění Ovzduší v Hradecko-Pardubické Oblasti (Ambient Air Pollution in Hradecko-Pardubicko); Výzkumná Zpráva za Úkol P 16-331-453; ČHMÚ: Praha, Czechoslovakia, 1982; In Czech.

33. Hrdá, J. (Ed.) Znečištění Ovzduší v Praze (Ambient Air Pollution in Prague); Výzkumná Zpráva za Úkol P 16-331-453; ČHMÚ: Praha, Czechoslovakia, 1983; In Czech.

34. Hrdá, J. Znečištěni Ovzduší v Mělnicko-Neratovické Oblasti (Ambient Air Pollution in Mělnicko-Neratovicko); Výzkumná Zpráva za Úkol P 16-331-453; ČHMÚ: Praha, Czechoslovakia, 1983; In Czech.

35. Hrdá, J. Znečištěni Ovzduši v Ostravské Oblasti (Ambient Air Pollution in the Ostrava Region); Výzkumná Zpráva za Úkol P 16-331-453; ČHMÚ: Praha, Czechoslovakia, 1984; In Czech.

36. Hrdá, J. Znečištěni Ovzduší v Brně (Ambient Air Pollution in Brno); Výzkumná Zpráva za Úkol P 16-331-453; ČHMÚ: Praha, Czechoslovakia, 1984; In Czech.

37. Hrdá, J. Znečištěni Ovzduší v Postižených Oblastech Západočeského Kraje (Ambient Air Pollution in Impacted Areas of West Bohemia); Výzkumná Zpráva za Úkol P 16-331-453; ČHMÚ: Praha, Czechoslovakia, 1985; In Czech.

38. Hrdá, J. Výzkum Znečištěni Ovzduši Pro Rozvoj Postižených Oblastí a Vybraných Odvětví Národního Hospodářství (Air Pollution Research for the Development of Contaminated Regions and Selected Branches of the National Economy); Závěrečná Zpráva za Úkol P 16-331-453; ČHMÚ: Praha, Czechoslovakia, 1985; In Czech.

39. Bubník, J. Analýza výsledků matematického modelování znečištění ovzduší v postižených oblastech ČSR (Analysis of results of mathematical air pollution modelling in contaminated regions of the CSR). Meteor. Zpr. 1986, 39, 164-169. 
40. Hrdá, J. Výzkum znečištění ovzduší pro rozvoj postižených oblastí a vybraných odvětví národního hospodářství (Air pollution research for the development of contaminated regions and selected branches of the national economy). Meteor. Zpr. 1986, 39, 134-136.

41. Weiss, K.; Hůnová, I.; Štengl, B. Znečištění ovzduší v postižených oblastech ČSR (Air pollution in infested areas of the CSR). Meteor. Zpr. 1986, 39, 141-146.

42. Symon, K. Aspects of air pollution-a public health hazard in Czechoslovakia. In Proceedings of the Inter-Regional Symposium on Criteria for Air Quality and Methods of Measurement, Geneva, Switzerland, 6-12 August 1963; World Health Organization: Geneva, Switzerland, 1963.

43. Bobak, M.; Marmot, M. East-west Mortality Divide and its Potential Explanations: Proposed Research Agenda. BMJ 1996, 312, 421. [CrossRef] [PubMed]

44. Bobak, M.; Leon, D.A. Air pollution and infant mortality in the Czech Republic, 1986-1988. Lancet 1992, 340, 1010-1014. [CrossRef]

45. Šrám, R. (Ed.) Impact of Air Pollution on Human Health: Teplice Program; Academia: Praha, Czech Republic, 2001.

46. Beneš, I.; Novák, J.; Pinto, J.P. Air Pollution in Teplice and Prachatice in 1995 and 2003: A Comparison after 8 Years. In Environmental Health in Central and Eastern Europe; Donnelly, K.C., Cizmas, L.H., Eds.; Springer: Dordrecht, The Netherlands, 2006.

47. Šrám, R.J.; Beneš, I.; Binková, B.; Dejmek, J.; Horstman, D.; Kotěšovec, F.; Otto, D.; Perreault, S.D.; Rubeš, J.; Selevan, S.G.; et al. Teplice program-the impact of air pollution on human health. Environ. Health Perspect. 1996, 104, 699-714.

48. Dostál, M.; Hertz-Picciotto, I.; Keller, J.R.; Dejmek, J.; Selevan, S.; Kotěšovec, F.; Nozicka, J.; Gomez-Caminero, A.; Wegienka, G.; Srám, R. Childhood morbidity and air pollution in the Teplice program. Casopis Lekaru Ceskych 2001, 140, 658-661.

49. Rubes, J.; Selevan, S.G.; Evenson, D.P.; Zudova, D.; Vozdova, M.; Zudova, Z.; Robbins, W.A.; Perreault, S.D. Episodic air pollution is associated with increased DNA fragmentation in human sperm without other changes in semen quality. Hum. Reprod. 2005, 20, 2776-2783. [CrossRef]

50. Slovik, S. Early needle senescence and thinning of the crown structure of Picea abies as induced by chronic SO2 pollution. II. Field data basis, model results and tolerance limits. Glob. Change Biol. 1996, 2, 459-477. [CrossRef]

51. Vacek, S.; Lepš, J. Changes in the Horizontal Structure in a Spruce Forest over a 9-year Period of Pollutant Exposure in the Krkonoše Mountains, Czechoslovakia. For. Ecol. Manag. 1987, 22, 291-295. [CrossRef]

52. Ardö, J. Remote Sensing of Forest Decline in the Czech Republic; Lund University Press: Lund, Sweden, 1998; Available online: http://citeseerx.ist.psu.edu/viewdoc/download?doi=10.1.1.494.2210\&rep=rep1\&type=pdf (accessed on 2 November 2019).

53. Emmer, I.M.; Fanta, J.; Kobus, A.T.; Kooijman, A.; Sevink, J. Reversing borealization as a means to restore biodiversity in Central-European mountain forests-An example from the Krkonoše Mountains, Czech Republic. Biodivers. Conserv. 1998, 7, 229-247. [CrossRef]

54. Akselsson, C.; Ardö, J.; Sverdrup, H. Critical Loads of Acidity for Forest Soils and Relationship to Forest Decline in the Northern Czech Republic. Environ. Monit. Assess. 2004, 98, 363-379. [CrossRef] [PubMed]

55. Hofmeister, J.; Oulehle, F.; Krám, P.; Hruška, J. Loss of nutrients due to litter raking compared to the effect of acidic deposition in two spruce stands, Czech Republic. Biogeochemistry 2008, 88, 139-151. [CrossRef]

56. Vacek, S.; Hůnová, I.; Vacek, Z.; Hejcmanová, P.; Podrázský, V.; Král, J.; Putalová, T.; Keith Moser, W. Effects of air pollution and climatic factors on Norway spruce forests in the Orlické hory Mts. (Czech Republic) 1979-2014. Eur. J. For. Res. 2015, 134, 1127-1142. [CrossRef]

57. Vacek, S.; Vacek, Z.; Remeš, J.; Bílek, L.; Hůnová, I.; Bulušek, D.; Putalová, T.; Král, J.; Simon, J. Sensitivity of unmanaged relict pine forest in the Czech Republic to climate change and air pollution. Trees 2017, 31, 1599-1617. [CrossRef]

58. Stoklasa, J.; Duinker, P. Social and Economic Consequences of Forest Decline in Czechoslovakia; IIASA Working Paper WP-88-028; IIASA: Laxenburg, Austria, 1988; Available online: http://pure.iiasa.ac.at/id/eprint/3177/1/ WP-88-028.pdf (accessed on 10 October 2019).

59. Materna, J. Air pollution and forestry in Czechoslovakia. Environ. Monit. Assess. 1989, 12, 227-235. [CrossRef]

60. Kubíková, J. Forest dieback in Czechoslovakia. Vegetatio 1991, 93, 101-108. [CrossRef] 
61. Fanta, J. Rehabilitating degraded forests in Central Europe into self-sustaining forest ecosystems. Ecol. Eng. 1997, 8, 289-297. [CrossRef]

62. Moldan, B.; Hak, T. Environment in the Czech Republic: A Positive and Rapid Change. Environ. Sci. Technol. 2007, 41, 358-362. [CrossRef]

63. Carrier, J.-G.; Kripple, E. Comprehensive Study of European Forests Assess Damage and Economic Losses from Air Pollution. Environ. Conserv. J. 1990, 17, 365-366. [CrossRef]

64. Lomský, B.; Materna, J.; Pfanz, H. (Eds.) $\mathrm{SO}_{2}$-Pollution and Forests Decline in the Ore Mountains; VÚLHM: Praha, Czech Republic, 2002; p. 342.

65. Mazurski, K.R. Communism and the Environment. Forum Appl. Res. Policy 1991, 5, 39-44.

66. Newman, J.R.; Novakova, E.; McClave, J.T. The influence of industrial air emissions on the nesting ecology of the house martin Delichon urbica in Czechoslovakia. Biol. Conserv. 1985, 31, 229-248. [CrossRef]

67. Kierdorf, U.; Bahelková, P.; Sedláček, F.; Kierdorf, H. Pronounced reduction of fluoride exposure in free-ranging deer in North Bohemia (Czech Republic) as indicated by the biomarkers skeletal fluoride content and dental fluorosis. Sci. Total Environ. 2012, 414, 686-695. [CrossRef] [PubMed]

68. Ustyak, S.; Petrikova, V. Heavy metal pollution of soils and crops in Northern Bohemia. Appl. Geochem. 1996, 11,77-80. [CrossRef]

69. Peters, N.E.; Cerny, J.; Havel, M.; Krejci, R. Temporal trends of bulk precipitation and stream waterchemistry in a small forested area, Krusnehory, northern Bohemia, Czech Republic. Hydrol. Process. 1999, 13, 2721-2741. [CrossRef]

70. Vesely, J.; Almquist-Jacobson, H.; Miller, L.M.; Norton, S.A.; Appleby, P.; Dixit, A.S.; Smol, J.P. The history and impact of air pollution at Čertovo Lake, southwestern Czech Republic. J. Paleolimnol. 1993, 8, $211-231$. [CrossRef]

71. Kramer, J. The Environmental Crisis in Eastern Europe: The Price for Progress. Slav. Rev. 1983, 42, $204-220$. [CrossRef]

72. Godzik, S. Air Pollution Problems in Some Central European Countries-Czechoslovakia, the German Democratic Republic and Poland. In Gaseous Air Pollutants and Plant Metabolism; Koziol, M.J., Whatley, F.R., Eds.; Butterworth: London, UK, 1984.

73. Turnock, D. Environmental problems and policies in East Central Europe: A changing agenda. GeoJournal 2001, 54, 485-505. [CrossRef]

74. Jedrychowski, W. Review of Recent Studies from Central and Eastern Europe Associating Respiratory Health Effects with High Levels of Exposure to "Traditional" Air Pollutants. Environ. Health Perspect. 1995, 103, $15-21$.

75. Rao, S.T.; Hogrefe, C.; Holloway, T.; Kallos, G. Long-Range Transport of Atmospheric Pollutants and Transboundary Pollution. In World Atlas of Atmospheric Pollution; Sokhi, R.S., Ed.; Anthem Press: London, UK, 2008.

76. Dovland, H. Monitoring European Transboundary Air Pollution. Environ. Sci. Policy Sustain. Dev. 1987, 29, 10-28. [CrossRef]

77. Hendrey, G.R.; Baalsrud, K.; Traaen, T.S.; Laake, M.; Raddum, G. Acid Precipitation: Some Hydrobiological Changes. Ambio 1976, 5, 224-227.

78. Tamm, C.O. Acid Precipitation: Biological Effects in Soil and on Forest Vegetation. Ambio 1976, 5, $235-238$.

79. Bengtsson, B.; Dickson, W.; Nyberg, P. Liming Acid Lakes in Sweden. Ambio 1980, 9, 34-36.

80. Binkley, D.; Hogberg, P. Tamm Review: Revisiting the influence of nitrogen on Swedish forests. For. Ecol. Manag. 2016, 368, 222-239. [CrossRef]

81. Vrablik, P.; Wildova, E.; Vrablikova, J. The Effect of Brown Coal Mining on the Environment and Health of the Population in Northern Bohemia (Czech Republic). Int. J. Clean Coal Energy 2017, 6, 1-13. [CrossRef]

82. Šauer, P.; Mádr, M. Economic growth and air pollution in the Czech Republic: Decoupling curves. IJEF 2012, 4, 205-213.

83. Fagin, A. Environmental Capacity Building in the Czech Republic. Environ. Plan. A 2001, 33, 589-606. [CrossRef]

84. Kára, J. Geopolitics and the Environment: The Case of Central Europe. Environ. Polit. 1992, 1, $186-195$. [CrossRef]

85. Waller, M.; Millard, F. Environmental politics in Eastern Europe. Environ. Polit. 1992, 1, 159-185. [CrossRef] 
86. Fagin, A. The development of civil society in the Czech Republic: The environmental sector as a measure of associational activity. J. Eur. Area Stud. 1999, 7, 91-108. [CrossRef]

87. Shriver, T.E.; Adams, A.E. Cycles of Repression and Tactical Innovation: The Evolution of Environmental Dissidence in Communist Czechoslovakia. Sociol. Q. 2010, 51, 329-354. [CrossRef]

88. Vavroušek, J. Environmental management in Czechoslovakia and succession states. Environ. Impact Assess. Rev. 1994, 14, 103-110. [CrossRef]

89. Vestreng, V.; Myhre, G.; Fagerli, H.; Reis, S.; Tarrasón, L. Twenty-five years of continuous sulphur dioxide emission reduction in Europe. Atmos. Chem. Phys. 2007, 7, 3663-3681. [CrossRef]

90. Braniš, M. Particulate Emission Inventory and Trends in Ambient Particulate Matter Concentrations in the Czech Republic between 1993 and 1999. Environ. Monit. Assess. 2003, 87, 123-132. [CrossRef]

91. CHMI. Air Pollution in the Czech Republic in 2012; Graphical Yearbook (Czech/English); Czech Hydrometeorological Institute: Prague, Czech Republic, 2013.

92. Pavlínek, P.; Pickles, J. Environmental Pasts/Environmental Futures in Post-socialist Europe. Environ. Polit. 2004, 13, 237-265. [CrossRef]

93. Fiala, J.; Rieder, M.; Dvořáková, M.; Livorová, H. Trends in the atmospheric and hydrological cycle of sulphur at catchments in the Czech Republic. Atmos. Environ. 2001, 35 (Suppl. 1), S55-S62. [CrossRef]

94. Hůnová, I.; Šantroch, J.; Ostatnická, J. Ambient Air Quality and Deposition Trends at Rural Stations in the Czech Republic during 1993-2001. Atmos. Environ. 2004, 38, 887-898. [CrossRef]

95. Kopáček, J.; Veselý, J. Sulfur and nitrogen emissions in the Czech Republic and Slovakia from 1850 till 2000. Atmos. Environ. 2005, 39, 2179-2188. [CrossRef]

96. Kerimray, A.; Rojas-Solórzano, L.; Torkmahalleh, M.A.; Hopke, P.K.; Gallachoir, B.P.O. Coal use for residential heating: Patterns, health implications and lessons learned. Energy Sustain. Dev. 2017, 40, 19-30. [CrossRef]

97. EMEP. 2019. Available online: https://www.ceip.at/webdab-emission-database (accessed on 20 September 2019).

98. Watts, R.; Lewtas, J.; Stevens, R.; Haerlage, T.; Pinto, J.; Williams, R.; Hattaway, K.; Míšková, I.; Beneš, I.; Kotěšovec, F.; et al. Czech-U.S. EPA Health Study: Assessment of Personal and Ambient Air Exposures to Pah and Organic Mutagens in the Teplice District of Northern Bohemia. Int. J. Environ. Anal. Chem. 1994, 56, 271-287. [CrossRef]

99. Pinto, J.P.; Stevens, R.K.; Willis, R.D.; Kellogg, R.; Mamane, Y.; Novak, J.; Santroch, J.; Benes, I.; Lenicek, J.; Bures, V. Czech Air Quality Monitoring and Receptor Modeling Study. Environ. Sci. Technol. 1998, 32, 843-854. [CrossRef]

100. Grønskei, K.E.; Bartonova, A.; Brechler, J.; Walker, S.E.; Larssen, S.J. Air pollution exposure monitoring and estimation VII. Estimation of population exposure in a central European airshed. Environ. Monit. 2000, 2, 344-350. [CrossRef] [PubMed]

101. Prechtel, A.; Alewell, C.; Armbruster, M.; Bittersohl, J.; Cullen, J.M.; Evans, C.D.; Helliwell, R.; Kopácek, J.; Marchetto, A.; Matzner, E.; et al. Response of sulphur dynamics in European catchments to decreasing sulphate deposition. Hydrol. Earth Syst. Sci. 2001, 5, 311-325. [CrossRef]

102. Bridges, K.S.; Jickells, T.D.; Davies, T.D.; Zeman, Z.; Hůnová, I. Aerosol, precipitation and cloud water observations on the Czech Krusne Hory plateau adjacent to a heavily industrialised valley. Atmos. Environ. 2002, 36, 353-360. [CrossRef]

103. Bridgman, H.A.; Davies, T.D.; Jickells, T.; Hůnová, I.; Tovey, K.; Bridges, K.; Surapipith, V. Air pollution in the Krusne hory region, Czech Republic during the 1990s. Atmos. Environ. 2002, 36, 3375-3389. [CrossRef]

104. Houthuis, D.; Breugelmans, O.; Hoek, G.; Vaskovi, E.; Miháliková, E.; Pastuszka, J.S.; Jirik, V.; Sachelarescu, S.; Lolova, D.; Meliefste, K.; et al. $\mathrm{PM}_{10}$ and $\mathrm{PM}_{2.5}$ concentrations in Central and Eastern Europe: Results from the Cesar study. Atmos. Environ. 2001, 35, 2757-2771. [CrossRef]

105. Stanners, D.; Bourdeau, P. Europe's Environment: The Dobris Assessment; EEA: Copenhagen, Denmark, 1995.

106. EEA. Air Quality in Europe-2019 Report; EEA Report No. 10/2019; EEA: Copenhagen, Denmark, 2019; Available online: https://www.eea.europa.eu/publications/air-quality-in-europe-2019/air-quality-in-europe2019/viewfile\#pdfjs.action=download (accessed on 30 November 2019).

107. WHO. Air Quality Guidelines for Europe; World Health Organization: Geneva, Switzerland, 1987.

108. WHO. WHO Air Quality Guidelines for Particulate Matter, Ozone, Nitrogen Dioxide and Sulfur Dioxide; Global Update 2005; World Health Organization: Geneva, Switzerland, 2006. 
109. EC. Directive 2008/50/EC of the European Parliament and of the Council of 21 May 2008 on Ambient Air Quality and Cleaner Air for Europe; OJEC L 152; EC: Brussel, Belgium, 2008.

110. Hůnová, I. Spatial Interpretation of ambient air quality for the territory of the Czech Republic. Environ. Pollut. 2001, 112, 107-119. [CrossRef]

111. Braniš, M.; Domasová, M. PM10 and black smoke in a small settlement: Case study from the Czech Republic. Atmos. Environ. 2003, 37, 83-92. [CrossRef]

112. Braniš, M.; Domasová, M.; Řezáčová, P. Particulate air pollution in a small settlement: The effect of local heating. Appl. Geochem. 2007, 22, 1255-1264. [CrossRef]

113. Pokorná, P.; Hovorka, J.; Kroužek, J.; Hopke, P.K. Particulate matter source apportionment in a village situated in industrial region of Central Europe. J. Air Waste Manag. 2013, 63, 1412-1421. [CrossRef]

114. Váňa, M.; Holoubek, I.; Pacl, A.; Pekárek, J.; Smrčková, V.; Machálek, P.; Helešic, J.; Šeda, Z.; Adamec, V.; Janouch, M.; et al. Quality of the Natural Environment in the Czech. Republic at the Regional Level; Results of the Kosetice Observatory; ČHMÚ: Praha, Czechoslovakia, 2001.

115. CHMI Website. Available online: http://portal.chmi.cz/files/portal/docs/uoco/isko/grafroc/grafroc_GB.html (accessed on 7 January 2020).

116. Hůnová, I.; Maznová, J.; Kurfürst, P. Trends in atmospheric deposition fluxes of sulphur and nitrogen in Czech forests. Environ. Pollut. 2014, 184, 668-675. [CrossRef] [PubMed]

117. Hůnová, I.; Bäumelt, V. Observation-based trends in ambient ozone in the Czech Republic over the past two decades. Atmos. Environ. 2018, 172, 157-167. [CrossRef]

118. Hůnová, I.; Bäumelt, V.; Modlík, M. Long-term trends in nitrogen oxides at different types of monitoring stations in the Czech Republic. Sci. Total Environ. 2020. [CrossRef]

119. Holoubek, I.; Klánová, J.; Jarkovský, J.; Kohoutek, J. Trends in background levels of persistent organic pollutants at Kosetice observatory, Czech Republic. Part I. Ambient air and wet deposition 1996-2005. J. Environ. Monit. 2007, 9, 557-563. [CrossRef] [PubMed]

120. Holoubek, I.; Houšková, L.; Šeda, L.; Holoubková, I.; Korínek, P.; Boháček, Z.; Čáslavský, J. Project TOCOEN. The fate of selected organic pollutants in the environment II. Air and rainwater 1988. Toxicol. Environ. Chem. 1990, 29, 19-27. [CrossRef]

121. Dvorská, A.; Lammel, G.; Klanova, J.; Holoubek, I. Kosetice, Czech Republic-Ten years of air pollution monitoring and four years of evaluating the origin of persistent organic pollutants. Environ. Pollut. 2008, 156, 403-408. [CrossRef]

122. Dvorská, A.; Lammel, G.; Holoubek, I. Recent trends of persistent organic pollutants in air in central Europe-Air monitoring in combination with air mass trajectory statistics as a tool to study the effectivity of regional chemical policy. Atmos. Environ. 2009, 43, 1280-1287. [CrossRef]

123. Degrendele, C.; Okonski, K.; Melymuk, L.; Landlová, L.; Kukučka, P.; Čupr, P.; Klánová, J. Size specific distribution of the atmospheric particulate PCDD/Fs, dl-PCBs and PAHs on a seasonal scale: Implications for cancer risks from inhalation. Atmos. Environ. 2014, 98, 410-416. [CrossRef]

124. Holoubek, I.; Kořínek, P.; Šeda, Z.; Schneiderová, E.; Holoubková, I.; Pacl, A.; Tríska, J.; Cudlín, P.; Cáslavský, J. The use of mosses and pine needles to detect persistent organic pollutants at local and regional scales. Environ. Pollut. 2000, 109, 283-292. [CrossRef]

125. Klánová, J.; Čupr, P.; Baráková, D.; Šeda, Z.; Anděl, P.; Holoubek, I. Can pine needles indicate trends in the air pollution levels at remote sites? Environ. Pollut. 2009, 157, 3248-3254. [CrossRef]

126. Thimmaiah, D.; Hovorka, J.; Hopke, P.K. Source Apportionment of Winter Submicron Prague Aerosols from Combined Particle Number Size Distribution and Gaseous Composition Data. Aerosol Air Qual. Res. 2009, 9, 209-236. [CrossRef]

127. Ǩimnáčová, D.; Ždímal, V.; Schwarz, J.; Smolík, J.; Řimnáč, M. Atmospheric aerosols in suburb of Prague: The dynamics of particle size distributions. Atmos. Res. 2011, 101, 539-552. [CrossRef]

128. Zíková, N.; Ždímal, V. Long-Term Measurement of Aerosol Number Size Distributions at Rural Background Station Košetice. Aerosol Air Qual. Res. 2013, 13, 1464-1474. [CrossRef]

129. Schwarz, J.; Chi, X.; Maenhaut, W.; Civiš, M.; Hovorka, J.; Smolík, J. Elemental and organic carbon in atmospheric aerosols at downtown and suburban sites in Prague. Atmos. Res. 2008, 90, 287-302. [CrossRef]

130. Vodička, P.; Schwarz, J.; Cusack, M.; Ždímal, V. Detailed comparison of OC/EC aerosol at an urban and a rural Czech background site during summer and winter. Sci. Total Environ. 2015, 518, 424-433. [CrossRef] 
131. Collins, J.F.; Brown, J.P.; Dawson, S.V.; Marty, M.A. Risk assessment for benzo[a]pyrene. Regul. Toxicol. Pharm. 1991, 13, 170-184. [CrossRef]

132. Kim, K.-H.; Jahan, S.A.; Kabir, E.; Brown, R.J.C. A review of airborne polycyclic aromatic hydrocarbons (PAHs) and their human health effects. Environ. Int. 2013, 60, 71-80. [CrossRef]

133. Křmumal, K.; Mikuška, P. Mass concentrations and lung cancer risk assessment of PAHs bound to $\mathrm{PM}_{1}$ aerosol in six industrial, urban and rural areas in the Czech Republic, Central Europe. Atmos. Pollut. Res. 2020, 11, 401-408. [CrossRef]

134. Kř̊mal, K.; Mikuška, P.; Horák, J.; Hopan, F.; Krpec, K. Comparison of emissions of gaseous and particulate pollutants from the combustion of biomass and coal in modern and old-type boilers used for residential heating in the Czech Republic, Central Europe. Chemosphere 2019, 229, 51-59. [CrossRef]

135. Lhotka, R.; Pokorná, P.; Zíková, N. Long-Term Trends in PAH Concentrations and Sources at Rural Background Site in Central Europe. Atmosphere 2019, 10, 687. [CrossRef]

136. Binková, B.; Černá, M.; Pastorková, A.; Jelínek, R.; Beneš, I.; Novák, J.; Šrám, R. Biological activities of organic compounds adsorbed onto ambient air particles: Comparison between the cities of Teplice and Prague during the summer and winter seasons 2000-2001. Mutat. Res. 2003, 525, 43-59. [CrossRef]

137. Pokorná, P.; Hovorka, J.; Klán, M.; Hopke, P.K. Source apportionment of size resolved particulate matter at a European air pollution hot spot. Sci. Total Environ. 2015, 502, 172-183. [CrossRef] [PubMed]

138. Mikuška, P.; Kř̆umal, K.; Večeřa, Z. Characterization of organic compounds in the $\mathrm{PM}_{2.5}$ aerosol in winter in an industrial urban area. Atmos. Environ. 2015, 105, 97-108. [CrossRef]

139. Vossler, T.; Cernikovsky, L.; Novak, J.; Placha, H.; Krejci, B.; Nikolova, I.; Chalupnickova, E.; Williams, R. An investigation of local and regional sources of fine particulate matter in Ostrava, the Czech Republic. Atmos. Pollut. Res. 2015, 6, 454-463.

140. Černikovský, L.; Krejčí, B.; Blažek, Z.; Volná, V. Transboundary air-pollution transport in the Czech-Polish border region between the cities of Ostrava and Katowice. Cent. Eur. J. Public Health 2016, 24, S45-S50. [CrossRef]

141. Pokorná, P.; Hovorka, J.; Hopke, P.K. Elemental composition and source identification of very fine aerosol particles in a European air pollution hot-spot. Atmos. Pollut. Res. 2016, 7, 671-679. [CrossRef]

142. Horak, J.; Kubonova, L.; Krpec, K.; Hopan, F.; Kubesa, P.; Motyka, O.; Laciok, V.; Dej, M.; Ochodek, T.; Placha, D. PAH emissions from old and new types of domestic hot water boilers. Environ. Pollut. 2017, 225, 31-39. [CrossRef]

143. Kozáková, J.; Pokorná, P.; Vodička, P.; Ondráčková, L.; Ondráček, J.; Křůmal, K.; Mikuška, P.; Hovorka, J.; Moravec, P.; Scwarz, J. The influence of local emissions and regional air pollution transport on a European air pollution hot spot. Environ. Sci. Pollut. Res. 2019, 26, 1675-1692. [CrossRef]

144. Leoni, C.; Hovorka, J.; Dočekalová, V.; Cajthaml, T.; Marvanová, S. Source Impact Determination using Airborne and Ground Measurements of Industrial Plumes. Environ. Sci. Technol. 2016, 50, 18. [CrossRef]

145. Leoni, C.; Pokorná, P.; Hovorka, J.; Massiol, M.; Topinka, J.; Zhao, Y.; Křůmal, K.; Cliff, S.; Mikuška, P.; Hopke, P.K. Source apportionment of aerosol particles at a European air pollution hot spot using particle number size distributions and chemical composition. Environ. Pollut. 2018, 234, 145-154. [CrossRef]

146. Ohlwein, S.; Kappeler, R.; Joss, M.K.; Künzli, N.; Hoffman, B. Health effects of ultrafine particles: A systematic literature review update of epidemiological evidence. Int. J. Public Health 2019, 64, 547-559. [CrossRef] [PubMed]

147. Schwarz, J.; Cusack, M.; Karban, J.; Chalupníčková, E.; Havránek, V.; Smolík, J.; Ždímal, V. PM 2.5 chemical composition at a rural background site in Central Europe, including correlation and air mass back trajectory analysis. Atmos. Res. 2016, 176, 108-120. [CrossRef]

148. Pokorná, P.; Hovorka, J.; Brejcha, J. Impact of Mining Activities on the Air Quality in the Village Nearby a Coal Strip Mine. IOP Conf. Ser. Earth Environ. Sci. 2016, 44, 032021. [CrossRef]

149. Schladitz, A.; Leníček, J.; Beneš, I.; Kováč, M.; Skorkovský, J.; Soukup, A.; Jandlová, J.; Poulain, L.; Plachá, H.; Loschau, G.; et al. Air quality in the German-Czech border region: A focus on harmful fractions of PM and ultrafine particles. Atmos. Environ. 2015, 122, 236-249. [CrossRef]

150. Horák, J.; Hopan, F.; Šyc, M.; Machálek, P.; Krpec, K.; Ocelka, T.; Tomšej, T. Estimation of selected pollutant emissions from solid-fuel combustion in small heating appliances. Chem. Listy 2011, 105, 851-855. 
151. Hovorka, J.; Pokorná, P.; Hopke, P.K.; Křůmal, K.; Mikuška, P.; Píšová, M. Wood combustion, a dominant source of winter aerosol in residential district in proximity to a large automobile factory in Central Europe. Atmos. Environ. 2015, 113, 98-107. [CrossRef]

152. Hezina, F.; Švec, H.; Postlová, H. Emise malých spalovacích zdrojů. (Emissions from small combustion sources). Ochrana Ovzduši 2013, 25, 6-12.

153. Tomsej, T.; Horak, J.; Tomsejova, S.; Krpec, K.; Klanova, J.; Dej, M.; Hopan, F. The impact of co-combustion of polyethylene plastics and wood in a small residential boiler on emissions of gaseous pollutants, particulate matter, PAHs and 1,3,5- triphenylbenzene. Chemosphere 2018, 196, 18-24. [CrossRef]

154. CEN. EN 303-5:2012 Heating Boilers-Part 5: Heating Boilers for Solid Fuels, Manually and Automatically Stoked, Nominal Heat Output of up to 500 KW; CEN: Brussels, Belgium, 2012.

155. Braniš, M. Air quality of Prague: Traffic as a main pollution source. Environ. Monit. Assess. 2009, 156, 377-390. [CrossRef]

156. Ondráček, J.; Schwarz, J.; Ždímal, V.; Andělová, L.; Vodička, P.; Bízek, V.; Tsai, C.-J.; Chen, S.-C.; Smolík, J. Contribution of the road traffic to air pollution in the Prague city (busy speedway and suburban crossroads). Atmos. Environ. 2011, 45, 5090-5100. [CrossRef]

157. Stolcpartova, J.; Pechout, M.; Dittrich, L.; Mazac, M.; Fenkl, M.; Vrbova, K.; Ondracek, J.; Vojtisek-Lom, M. Internal Combustion Engines as the Main Source of Ultrafine Particles in Residential Neighborhoods: Field Measurements in the Czech Republic. Atmosphere 2015, 6, 1714-1735. [CrossRef]

158. Rossner, P., Jr.; Topinka, J.; Hovorka, J.; Milcova, A.; Krouzek, J.; Sram, R.J. An acellular assay to assess the genotoxicity of complex mixtures of organic pollutants bound on size segregated aerosol. Part II: Oxidative damage to DNA. Toxicol. Lett. 2010, 198, 312-316. [CrossRef]

159. Šrám, R.J.; Dostál, M.; Libalová, H.; Rossner, P.; Rossnerová, A.; Svecova, V.; Topinka, J.; Bartonova, A. The European hot spot of $\mathrm{B}[\mathrm{a}] \mathrm{P}$ and $\mathrm{PM}_{2.5}$ exposure-the Ostrava region, Czech Republic: Health research results. ISRN Public Health 2013, 2013. [CrossRef]

160. Topinka, J.; Hovorka, J.; Milcova, A.; Schmuczerova, J.; Krouzek, J.; Rossner, P.Jr.; Sram, R.J. An acellular assay to assess the genotoxicity of complex mixtures of organic pollutants bound on size segregated aerosol. Part I: DNA adducts. Toxicol. Lett. 2010, 198, 304-311. [CrossRef] [PubMed]

161. Topinka, J.; Milcova, A.; Schmuczerova, J.; Krouzek, J.; Hovorka, J. Ultrafine particles are not major carriers of carcinogenic PAHs and their genotoxicity in size-segregated aerosols. Mutat. Res. Genet. Toxicol. Environ. Mutagen. 2013, 754, 1-6. [CrossRef]

162. Topinka, J.; Rossner, P., Jr.; Milcová, A.; Schmurzerová, J.; Pěnčíková, K.; Rossnerová, A.; Ambrož, A.; Štolcpartová, J.; Bendl, J.; Hovorka, J.; et al. Day-to-day variability of toxic events induced by organic compounds bound to size segregated atmospheric aerosol. Environ. Pollut. 2015, 202, 135-145. [CrossRef]

163. Jiřík, V.; Machaczka, O.; Miturová, H.; Tomášek, I.; Šlachtová, H.; Janoutová, J.; Velická, H.; Janout, V. Air Pollution and Potential health risk in Ostrava Region-a review. Cent. Eur. J. Public Health 2016, 24, S4-S17. [CrossRef]

164. Velická, H.; Puklová, V.; Keder, J.; Brabec, M.; Malý, M.; Bobák, M.; Kotlík, B.; Jiř́ík, V.; Janout, V.; Kazmarová, H. Asthma exacerbations and symptom variability in children due to short-term ambient air pollution changes in Ostrava, Czech Republic. Cent. Eur. J. Public Health 2015, 23, 292-298.

165. Braniš, M.; Vyškovská, J.; Malý, M.; Hovorka, J. Association of size-resolved number concentrations of particulate matter with cardiovascular and respiratory hospital admissions and mortality in Prague, Czech Republic. Inhal. Toxicol. 2010, 22 (Suppl. 2), 21-28. [CrossRef]

166. Šrám, R.J.; Binkova, B.; Dostal, M.; Merkerova-Dostalova, M.; Libalova, H.; Milcova, A.; Rossner, P.Jr.; Rossnerova, A.; Schmuczerova, J.; Svecova, V.; et al. Health impact of air pollution to children. Int. J. Hyg. Environ. Health 2013, 216, 533-540. [CrossRef]

167. Dostal, M.; Pastorkova, A.; Rychlik, S.; Rychlikova, E.; Svecova, V.; Schallerova, E.; Sram, R.J. Comparison of child morbidity in regions of Ostrava, Czech Republic, with different degrees of pollution: A retrospective cohort study. Environ. Health 2013, 12, 74. [CrossRef] [PubMed]

168. Finlayson-Pitts, B.J.; Pitts, J.N. Chemistry of the Upper and Lower Atmosphere; Academia Press: San Diego, CA, USA, 2000.

169. Fiala, J.; Cernikovsky, L.; de Leeuw, F.; Kurfürst, P. Air Pollution by Ozone in Europe in Summer 2003; EEA Topic Report 3/2003; European Environment Agency: Copenhagen, Denmark, 2003. 
170. Seinfeld, J.H.; Pandis, S.N. Atmospheric Chemistry and Physics: From Air Pollution to Climate Change, 2nd ed.; John Wiley \& Sons Inc.: New York, NY, USA, 2006.

171. Hůnová, I.; Brabec, M.; Malý, M. What are the principal factors affecting ambient ozone concentrations in Czech mountain forests? Front. For. Glob. Change 2019. [CrossRef]

172. Hůnová, I.; Kurfürst, P.; Baláková, L. Areas under high ozone and nitrogen loads are spatially disjunct in Czech forests. Sci. Total Environ. 2019, 656, 567-575. [CrossRef] [PubMed]

173. UN/ECE. Mapping Manual Revision. UN-ECE Convention on Long-Range Transboundary Air Pollution. Manual on the Methodologies and Criteria for Modelling and Mapping Critical Loads and Levels and Air Pollution Effects, Risks and Trends. 2004. Available online: http://www.icp-mapping.org (accessed on 15 September 2019).

174. Hůnová, I. Ambient air quality for the territory of the Czech Republic in 1996-1999 expressed by three essential factors. Sci. Total Environ. 2003, 303, 245-251. [CrossRef]

175. Hůnová, I.; Livorová, H.; Ostatnická, J. Potential Ambient Ozone Impact on Ecosystems in the Czech Republic as Indicated by Exposure Index AOT40. Ecol. Indic. 2003, 3, 35-47. [CrossRef]

176. Hůnová, I.; Schreiberová, M. Ambient ozone phytotoxic potential over the Czech forests as assessed by AOT40. IForest 2012, 5, 153-162. [CrossRef]

177. Tolasz, R.; Miková, T.; Valeriánová, A.; Voženílek, V. Climate Atlas of Czechia; CHMI: Praha, Czech Republic, 2007.

178. Hůnová, I.; Horálek, J.; Schreiberová, M.; Zapletal, M. Ambient ozone exposure in Czech forests: A GIS-based approach to spatial distribution assessment. Sci. World J. 2012, 10. [CrossRef]

179. Krupa, S.V.; Legge, A.H. Passive sampling of ambient, gaseous air pollutants: An assessment from an ecological perspective. Environ. Pollut. 2000, 107, 31-45. [CrossRef]

180. Hůnová, I.; Matoušková, L.; Srněnský, R.; Koželková, K. Ozone influence on native vegetation in the Jizerske hory Mts. of the Czech Republic: Results based on ozone exposure and ozone-induced visible symptoms. Environ. Monit. Assess. 2011, 183, 501-515. [CrossRef]

181. Hůnová, I.; Stoklasová, P.; Schovánková, J.; Kulasová, A. Spatial and Temporal Trends of Ozone Distribution in the Jizerské hory Mountains of the Czech Republic. Environ. Sci. Pollut. Res. 2016, 23, 377-387. [CrossRef]

182. Hůnová, I. Measurements of ground-level ozone in Czech mountain forests: What we have learnt from using diffusive samplers. Eur. J. Environ. Sci. 2017, 7, 125-129. [CrossRef]

183. Vlasáková-Matoušková, L.; Hůnová, I. Stomatal ozone flux and visible leaf injury in native juvenile trees of Fagus Sylvatica, L.: A field study from the Jizerske hory Mts., the Czech Republic. Environ. Sci. Pollut. Res. 2015, 22, 10034-10046. [CrossRef] [PubMed]

184. Šrámek, V.; Novotný, R.; Bednárová, M.; Uhlírová, H. Monitoring of ozone risk for forest in the Czech Republic: Preliminary results. Sci. World J. 2007, 7, 78-83. [CrossRef] [PubMed]

185. Šrámek, V.; Novotný, R.; Vejpustková, M.; Hůnová, I.; Uhlî́rová, H. Monitoring of ozone effects on the vitality and increment of Norway spruce and European beech in Central European forests. J. Environ. Monit. 2012, 14, 1696-1702. [CrossRef]

186. Matoušková, L.; Novotný, R.; Hůnová, I.; Buriánek, V. Visible foliar injury as a tool for the assessment of surface ozone impact on native vegetation: A case study from the Jizerske hory Mts. J. For. Sci. 2010, 56, 177-182. [CrossRef]

187. Hůnová, I.; Novotný, R.; Uhlírová, H.; Vráblík, T.; Horálek, J.; Lomský, B.; Šrámek, V. The impact of ambient ozone on mountain spruce forests in the Czech Republic as indicated by malondialdehyde. Environ. Pollut. 2010, 158, 2393-2401. [CrossRef]

188. Zapletal, M.; Pretel, J.; Chroust, P.; Cudlín, P.; Edwards-Jonášová, M.; Urban, O.; Pokorný, R.; Czerný, R.; Hůnová, I. The influence of climate change on stomatal ozone flux to forest ecosystem. Environ. Pollut. 2012, 169, 267-273. [CrossRef]

189. Cailleret, M.; Ferretti, M.; Gessler, A.; Rigling, A.; Schaub, M. Ozone effects on European forest growth-Towards an integrative approach. J. Ecol. 2018, 106, 1377-1389. [CrossRef]

190. Hůnová, I.; Malý, M.; Řezáčová, J.; Braniš, M. Association between Ambient Ozone and Health Outcomes in Prague. Int. Arch. Occup. Environ. Health 2013, 86, 89-97. [CrossRef]

191. Hůnová, I.; Brabec, M.; Malý, M.; Knobová, V.; Braniš, M. Major heat waves of 2003 and 2006 and health outcomes in Prague. Air Qual. Atmos. Health 2017, 10, 183-194. [CrossRef] 
192. Fottová, D. Trends in Sulphur and Nitrogen Deposition Fluxes in the GEOMON Network, Czech Republic, between 1994 and 2000. Water Air Soil Pollut. 2003, 150, 73-87. [CrossRef]

193. Hůnová, I.; Kurfürst, P.; Stráník, V.; Modlík, M. Nitrogen deposition to forest ecosystems with focus on its different forms. Sci. Total Environ. 2017, 575, 791-798. [CrossRef] [PubMed]

194. Bytnerowicz, A.; Fenn, M.E. Nitrogen deposition in California forests: A review. Environ. Pollut. 1996, 92, 127-146. [CrossRef]

195. Thimonier, A.; Kosonen, Z.; Braun, S.; Rihm, B.; Schleppi, P.; Schmitt, M.; Seitler, E.; Waldner, P.; Thoni, L. Total deposition of nitrogen in Swiss forests: Comparison of assessment methods and evaluation of changes over two decades. Atmos. Environ. 2019, 198, 335-350. [CrossRef]

196. Hůnová, I.; Kurfürst, P.; Maznová, J.; Coňková, M. The contribution of occult precipitation to sulphur deposition in the Czech Republic. Erdkunde 2011, 65, 247-259. [CrossRef]

197. Hůnová, I.; Kurfürst, P.; Vlček, O.; Stráník, V.; Stoklasová, P.; Schovánková, J.; Srbová, D. Towards a Better Spatial Quantification of Nitrogen Deposition: A Case Study for Czech Forests. Environ. Pollut. 2016, 213, 1028-1041. [CrossRef]

198. Elias, V.; Tesar, M.; Buchtele, J. Occult precipitation: Sampling, chemical analysis and process modelling in the Sumava Mts. (Czech Republic) and in the Taunus Mts. (Germany). J. Hydrol. 1995, 166, 409-420. [CrossRef]

199. Fisak, J.; Tesar, M.; Rezacova, D.; Elias, V.; Weignerova, V.; Fottova, D. Pollutant concentrations in fog and low cloud water at selected sites of the Czech Republic. Atmos. Res. 2002, 64, 75-87. [CrossRef]

200. Křeček, J.; Palán, L.; Stuchlík, E. Acid atmospheric deposition in a forested mountain catchment. IForest 2017, 10, 680-686. [CrossRef]

201. Palán, L.; Křeček, J. Interception and Fog Drip Estimates in Fragmented Mountain Forests. Environ. Process. 2018, 5, 727-742. [CrossRef]

202. Hůnová, I.; Brabec, M.; Malý, M.; Valeriánová, A. Revisiting fog as an important constituent of the atmosphere. Sci. Total Environ. 2018, 656, 1490-1499. [CrossRef] [PubMed]

203. Hůnová, I.; Brabec, M.; Malý, M.; Valeriánová, A. Long-term trends in fog occurrence in the modern-day Czech Republic, Central Europe. Sci. Total Environ. 2019, in press. [CrossRef]

204. Bohdalkova, L.; Novak, M.; Voldrichova, P.; Prechova, E.; Veselovsky, F.; Erbanova, L.; Krachler, M.; Komarek, A.; Mikova, J. Atmospheric deposition of beryllium in Central Europe: Comparison of soluble and insoluble fractions in rime and snow across a pollution gradient. Sci. Total. Environ. 2012, 439, $26-34$. [CrossRef]

205. Voldrichova, P.; Chrastny, V.; Sipkova, A.; Farkas, J.; Novak, M.; Stepanova, M.; Krachler, M.; Veselovsky, F.; Blaha, V.; Prechova, E.; et al. Zinc isotope systematics in snow and ice accretions in Central European mountains. Chem. Geol. 2014, 388, 130-141. [CrossRef]

206. Cimova, N.; Novak, M.; Chrastny, V.; Curik, J.; Veselovsky, F.; Blaha, V.; Prechova, E.; Pasava, J.; Houskova, M.; Bohdalkova, L.; et al. Lead fluxes and $206 \mathrm{~Pb} / 207 \mathrm{~Pb}$ isotope ratios in rime and snow collected at remote mountain-top locations (Czech Republic, Central Europe): Patterns and sources. Atmos. Environ. 2016, 143, 51-59. [CrossRef]

207. Novak, M.; Sipkova, A.; Chrastny, V.; Stepanova, M.; Voldrichova, P.; Veselovsky, F.; Prechova, E.; Blaha, V.; Curik, J.; Farkas, J.; et al. Cu-Zn isotope constraints on the provenance of air pollution in Central Europe: Using soluble and insoluble particles in snow and rime. Environ. Pollut. 2016, 218, 1135-1146. [CrossRef]

208. Suchara, I.; Sucharová, J. Distribution of 36 element deposition rates in a historic mining and smelting area as determined through fine scale biomonitoring techniques, Part II: Relative long-term accumulated atmospheric deposition levels. Water Air Soil Pollut. 2004, 153, 229-252. [CrossRef]

209. Sucharova, J.; Suchara, I. Distribution of 36 element deposition rates in a historic mining and smelting area as documented through fine-scale biomonitoring techniques. Part I: Relative and absolute current atmospheric deposition levels detected by moss analyses. Water Air Soil Pollut. 2004, 153, 205-228. [CrossRef]

210. Conkova, M.; Kubiznakova, J. Lead isotope ratios in tree bark pockets: An indicator of past air pollution in the Czech Republic. Sci. Total Environ. 2008, 404, 440-445. [CrossRef]

211. Suchara, I. Temporal and spatial changes in spruce bark acidity at the scale of the Czech Republic in the last two decades, and the current abundance of epiphytic lichen Hypogymnia physodes. Water Air Soil Pollut. 2012, 223, 1685-1697. [CrossRef] 
212. Suchara, I.; Sucharová, J.; Holá, M. The influence of contrasting ambient SO2 concentrations in the Czech Republic in 1995 and in 2000 on the characteristics of spruce bark, used as an air quality indicator. Ecol. Indic. 2014, 39, 144-152. [CrossRef]

213. Suchara, I.; Sucharová, J.; Holá, M. Spatiotemporal changes in atmospheric deposition rates across the Czech Republic estimated in the selected biomonitoring campaigns. Examples of results available for landscape ecology and land use planning. J. Landsc. Ecol. 2015, 8, 1-19. [CrossRef]

214. Vile, M.A.; Wieder, K.; Novák, M. 200 years of Pb deposition throughout the Czech Republic: Patterns and Sources. Environ. Sci. Technol. 2000, 34, 12-21. [CrossRef]

215. Zuna, M.; Ettler, V.; Šebek, O.; Mihaljevič, M. Mercury accumulation in peatbogs at Czech sites with contrasting pollution histories. Sci. Total Environ. 2012, 424, 322-330. [CrossRef]

216. Zuna, M.; Mihaljevič, M.; Šebek, O.; Ettler, V.; Handley, M.; Navrátil, T.; Goliáš, V. Recent lead deposition trends in the Czech Republic as recorded by peat bogs and tree rings. Atmos. Environ. 2011, 45, 4950-4958. [CrossRef]

217. Doušová, B.; Erbanová, L.; Novák, M. Arsenic in atmospheric deposition at the Czech-Polish border: Two sampling campaigns 20 years apart. Sci. Total Environ. 2007, 387, 185-193. [CrossRef]

218. Kopáček, J.; Hejzlar, J.; Stuchlík, E.; Fott, J.; Veselý, J. Reversibility of acidification of mountain lakes after reduction in nitrogen and sulphur emissions in Central Europe. Limnol. Oceanogr. 1998, 43, 357-361. [CrossRef]

219. Hruška, J.; Moldan, F.; Krám, P. Recovery from acidification in central Europe-observed and predicted changes of soil and streamwater chemistry in the Lysina catchment, Czech Republic. Environ. Pollut. 2002, 120, 261-274. [CrossRef]

220. Vrba, J.; Kopáček, J.; Fott, J.; Kohout, L.; Nedbalová, L.; Pražáková, M.; Soldán, T.; Schaumurg, J. Long-term studies (1871-2000) on acidification and recovery of lakes in the Bohemian Forest (central Europe). Sci. Total Environ. 2003, 310, 73-85. [CrossRef]

221. Oulehle, F.; Hofmeister, J.; Cudlín, P.; Hruška, J. The effect of reduced atmospheric deposition on soil and soil solution chemistry at a site subjected to long-term acidification, Načetín, Czech Republic. Sci. Total Environ. 2006, 370, 532-544. [CrossRef]

222. Oulehle, F.; McDowell, W.H.; Aitkenhead-Peterson, J.A.; Krám, P.; Hruška, J.; Navrátil, T.; Buzek, F.; Fottová, D. Long-Term Trends in Stream Nitrate Concentrations and Losses Across Watersheds Undergoing Recovery from Acidification in the Czech Republic. Ecosystems 2008, 11, 410-425. [CrossRef]

223. Novotný, R.; Buriánek, V.; Šrámek, V.; Hůnová, I.; Skořepová, I.; Zapletal, M.; Lomský, M. Nitrogen deposition and its impact on forest ecosystems in the Czech Republic-Change in soil chemistry and ground vegetation. IFOREST 2016, 10, 48-54. [CrossRef]

224. Lomský, B.; Šrámek, V.; Novotný, R. Changes in the air pollution load in the Jizera Mts: Effects on the health status and mineral nutrition of the young Norway spruce stands. Eur. J. For. Res. 2012, 131, 757-771. [CrossRef]

225. Buriánek, V.; Novotný, R.; Hellebrandová, K.; Šrámek, V. Ground vegetation as an important factor in the biodiversity of forest ecosystems and its evaluation in regard to nitrogen deposition. J. For. Sci. 2013, 59, 238-252. [CrossRef]

226. Altman, J.; Fibich, P.; Santruckova, H.; Dolezal, J.; Stepanek, P.; Kopacek, J.; Hunova, I.; Oulehle, F.; Tumajer, J.; Cienciala, E. Environmental factors exert strong control over the climate-growth relationships of Picea abies in Central Europe. Sci. Total Environ. 2017, 609, 506-516. [CrossRef] [PubMed]

227. Cienciala, E.; Russ, R.; Šantrůčková, H.; Altman, J.; Kopáček, J.; Altman, J.; Kopáček, J.; Hůnová, I.; Štěpánek, P.; Oulehle, F.; et al. Discerning environmental factors affecting current tree growth in Central Europe. Sci. Total Environ. 2016, 573, 541-554. [CrossRef] [PubMed]

(C) 2020 by the author. Licensee MDPI, Basel, Switzerland. This article is an open access article distributed under the terms and conditions of the Creative Commons Attribution (CC BY) license (http://creativecommons.org/licenses/by/4.0/). 